\title{
Retrospective analysis of the preparation and application of immunotherapy in cancer treatment (Review)
}

\author{
JIACHEN LU ${ }^{1,2^{*}}$, JIANING DING ${ }^{1,2^{*}}$, ZHAOXIA LIU ${ }^{1}$ and TINGTAO CHEN ${ }^{1,3}$

\begin{abstract}
${ }^{1}$ Department of Obstetrics and Gynecology, The Second Affiliated Hospital of Nanchang University, Nanchang, Jiangxi 330006; ${ }^{2}$ Queen Mary School, Nanchang University; ${ }^{3}$ National Engineering Research Center for Bioengineering Drugs and Technologies, Institute of Translational Medicine, Nanchang University, Nanchang, Jiangxi 330031, P.R. China
\end{abstract}

Received October 5, 2021; Accepted December 20, 2021

DOI: $10.3892 /$ ijo.2022.5302

\begin{abstract}
Monoclonal antibody technology plays a vital role in biomedical and immunotherapy, which greatly promotes the study of the structure and function of genes and proteins. To date, monoclonal antibodies have gone through four stages: murine monoclonal antibody, chimeric monoclonal antibody, humanised monoclonal antibody and fully human monoclonal antibody; thousands of monoclonal antibodies have been used in the fields of biology and medicine, playing a special role in the pathogenesis, diagnosis and treatment of disease. In this review, we compare the advantages and disadvantages of hybridoma technology, phage display technology, ribosome display technology, transgenic mouse technology, single B cell monoclonal antibody generation technologies, and forecast the promising applications of these technologies in clinical medicine, disease diagnosis and tumour treatment.
\end{abstract}

\section{Contents}

1. Introduction

2. Immunotherapy and antibodies

3. Monoclonal antibody preparation techniques and their applications

Correspondence to: Dr Tingtao Chen, National Engineering Research Center for Bioengineering Drugs and Technologies, Institute of Translational Medicine, Nanchang University, 1299 Xuefu Road, Honggu, Nanchang, Jiangxi 330031, P.R. China

E-mail: chentingtao1984@163.com

Professor Zhaoxia Liu, Department of Obstetrics and Gynecology, The Second Affiliated Hospital of Nanchang University, 1 Minde Road, Donghu, Nanchang, Jiangxi 330006, P.R. China

E-mail: 1zxia77@163.com

*Contributed equally

Key words: tumour, immunotherapy, monoclonal antibody, phage display technology, A single B cell monoclonal antibody generation technology
4. Application of monoclonal antibodies in tumour therapy

5. Monoclonal antibody drugs and market value

6. Prospects

\section{Introduction}

Tumours are a series of diseases caused by uncontrolled cell proliferation mainly due to a change in genes. A tumour often forms in a local site and invades the surrounding tissues so as to induce metastasis (1). As the most prevalent disease in the world, it arises under the synergistic and sequential effects of multiple oncogenic factors such as chemical carcinogens, ionising radiation, viruses and bacteria, which can induce the transformation of proto-oncogenes to oncogenes and the inactivation of tumour-suppressor genes $(2,3)$. Under the influence of these factors, alterations in apoptosis regulatory genes and DNA repair genes develop, accompanied by abnormal expression levels of cellular proteins (4).

According to the cellular characteristics, tumour morphology, treatment method and degree of harm to the body, tumours can be divided into: i) solid tumours which can be detected by clinical examination such as X-ray, CT scan, ultrasound, or palpation $(5,6)$, and ii) non-solid tumours which are mainly present in the blood circulation and not visible to the naked eye or on imaging (7). In general, non-solid tumours have a wide distribution of tumour cells in the blood and bone marrow, and thus cannot be removed surgically, but only by chemotherapy (8). In contrast, the majority of solid tumours can be treated with a wider range of strategies, such as surgery, chemotherapy, radiotherapy, immunotherapy, tumour biotherapy, oncolytic virotherapy, target treatment, hormone therapy, minimally invasive interventional therapy, microwave therapy, radiofrequency therapy and cryotherapy $(9,10)$. Among these treatments, immunotherapy, characterised as having high specificity, precise targeting capability, powerful antitumour effects and low side effects, relies on activation of the patient's own immune system to kill tumour cells which makes the target different from other treatments (surgeries, chemotherapy, radiotherapy and targeted therapies), and shows bright and unparalleled prospects due to the unusual and miraculous effects (11). 
As the most prominent component of immunotherapy, monoclonal antibodies (mAbs) are highly homogeneous antibodies produced by a single B-cell clone and directed only against a specific antigenic epitope (12). While it has the advantages of high purity, high sensitivity, high specificity, low cross-reactivity and low cost of preparation, some disadvantages also exist, such as its production and preparation requiring certain technology (13). However, with the optimisation of preparation techniques and the production of numerous mAb drugs (such as abciximab and rituximab) over the years, the scope of application of mAbs has gradually broadened, and they have been widely used in immune checkpoint therapy, targeted tumour therapy, radioimmunotherapy and near-infrared photoimmunotherapy (NIR-PIT) to date, specifically showing great development prospect in tumour therapy $(9,14,15)$. As mAb research can be applied to many other areas of technical research, it not only drives the research process of full human $\mathrm{mAb}$ preparation, but also perfectly demonstrates its unparalleled value in tumour control and treatment research, under the efforts of countless researchers.

In view of these factors, this review will focus on the relatively mature techniques for the preparation of $\mathrm{mAbs}$ and the application of mAbs to demonstrate the importance of $\mathrm{mAb}$ research. This review reviewed 242 articles published mainly between 2005 and 2021, including the PubMed, Excerpt Medica Database, Medline, OVID and the Cochrane Library databases, by searching the key word monoclonal antibody, immunotherapy or tumour.

\section{Immunotherapy and antibodies}

Tumour immunotherapy is a therapy used to restore the normal antitumour immune response of the body by restarting and maintaining the tumour immune cycle for tumour control and clearance, which has a major impact on the treatment of metastatic tumours and has altered the standards of care for many types of tumours (16). As its indispensable components, antibodies are specific binding immunoglobulins produced by plasma cells derived from B lymphocytes or memory cells in response to antigen stimulation by the body's immune system $(17,18)$. Its functions refer to combining with antigens and effectively removing foreign bodies such as invading microorganisms and parasites (19).

In general, antibodies can be divided into polyclonal antibodies and mAbs. Polyclonal antibodies are produced from multiple B cell clones after the body is stimulated by a variety of antigenic determinants, which can be regarded as a mixture of multiple mAbs (20). In contrast, mAbs are the antibodies that can target the particular antigen determining cluster, characterised as high specificity, strong binding force, high purity, low cost and mass production (18). As a kind of highly specific and homologous antibody, the mAb was first produced by Köhler and Milstein in 1975 with the use of the hybridoma technique, which used the HAT culture medium to screen for hybridoma cells that could grow steadily, recognise a particular antigenic epitope and produce mAbs (21). In 1982, Levy of the Stanford Medical Centre in the US prepared a unique mAb against B-cell lymphoma; the patient's condition was alleviated and the tumour disappeared after treatment with this unique antibody. This was the first time that mAbs had been used in clinical treatment (22), and showed promise for application as targeted therapies for tumours, inflammation, and cardiovascular, autoimmune and infectious diseases. Due to the great contribution that hybridoma technology has made to the field of life sciences, Milstein and Köhler were awarded the Nobel Prize in Medicine and Physiology in 1984 (14), which indicated the people's recognition of mAbs and how optimistic people are about their prospects to some extent. Soon after this, orthoclone was produced by Ortho Biotech, which was also named muromomab-CD3. This was approved by the food and drug administration (FDA) as the first mAb drug in 1986 and was used to inhibit acute rejection of kidney transplantation and treat human diseases (23), opening a new era of mAb therapy.

To date, mAbs have undergone different stages of optimisation and development, including murine mAbs, humanised mAbs and fully human mAbs (24). The advent of hybridoma technology has made possible the implementation of the large-scale preparation of uniform murine mAbs (25). Compared with the polyclonal antibodies studied in the past, murine mAbs showed a huge difference in terms of specificity and consistency, as even the different batches of polyclonal antibodies prepared with the same antigen cannot guarantee their consistency but perfectly consistent murine mAbs can be produced continuously once the hybridoma is successfully prepared $(21,26)$. Nevertheless, the murine mAbs, as the heterologous protein, may lead to an immune response and the production of the human anti-murine antibody (HAMA) in vivo which can in turn clear the murine mAbs, resulting in the emergence of autoimmune diseases and an ultimate reduction in therapeutic effectiveness $(27,28)$.

The humanised $\mathrm{mAb}$ refers to the murine $\mathrm{mAb}$ reconstructed by gene cloning and DNA recombination (29). The construction forms the constant parts of $\mathrm{mAb}$ (the $\mathrm{CH}$ and $\mathrm{CL}$ regions) or all parts of the $\mathrm{mAb}$ encoded by human antibody genes, leading to the basic preservation of the affinity and specificity of the original murine $\mathrm{mAb}$ and a reduction of its heterology (30). As the most widely used mAb, the advantage of humanised mAbs is that they can overcome the human anti-murine antibody reaction, preventing the rapid elimination of mAbs as foreign proteins by the immune system, and improving the biological activity of mAbs (31).

As the ideal antibody for treatment, fully human mAbs have the humanised $\mathrm{V}$ and $\mathrm{C}$ regions (29). With the use of transgenes, the transchromosome technique or some other technique, all of the genes encoding human antibodies can be transferred into genetically engineered animals with their antibody genes deleted, so that the animals can express human antibodies and achieve the goal of full humanisation (32). At present, the human hybridoma technique, the EBV transformation of B lymphocytes, phage display, the transgenic mouse technique and the preparation of a single B cell antibody can all be used to produce fully human mAbs (33-35) (Fig. 1). Among them, mAbs obtained by transgenic mouse technology are relatively complete, and those obtained by phage display technology are generally incomplete (35). 
A
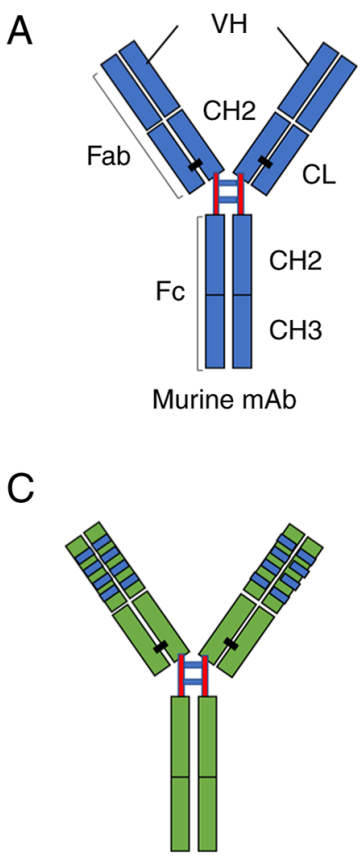

Humanized mAb
B

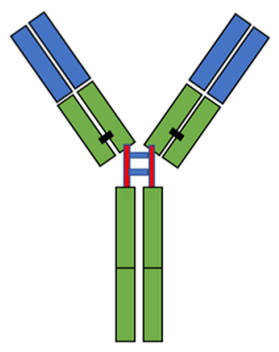

Chimeric mAb

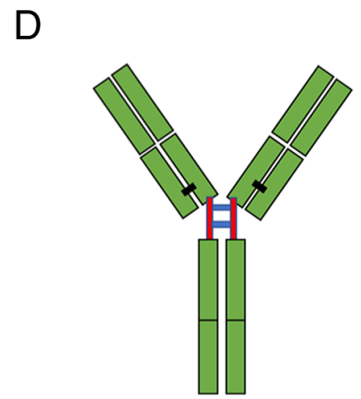

Human mAb

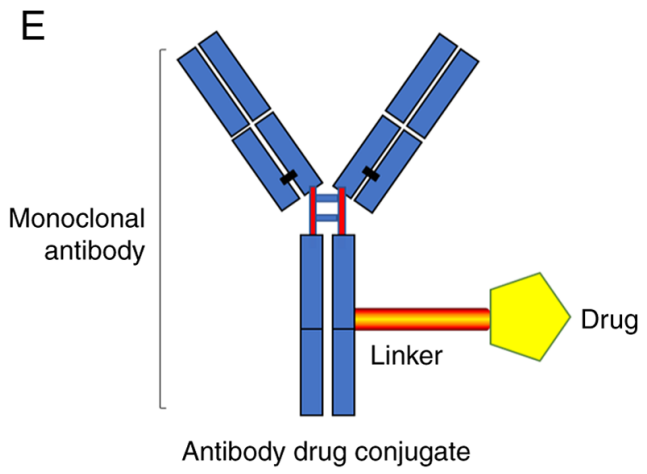

Antibody drug conjugate

Figure 1. Schematic overview of humanization from murine antibodies (blue domains) to fully human antibodies (green domains) and associated suffixes (A) The murine monoclonal antibody. (B) The chimeric monoclonal antibody: V regions are of murine origin, and the rest of the chains are of human origin. (C) Humanized monoclonal antibody: only contain the hypervariable segments of murine origin. (D) Human monoclonal. (E) Antibody-drug conjugate. $\mathrm{CH}$, domains of the $\mathrm{C}$ region of the heavy chain; CL, C domain of the light chain; VH, V domain of the heavy chain; VL, $\mathrm{V}$ domain of the light chain; Fab and $\mathrm{Fc}$, fragments resulting from proteolysis.

\section{Monoclonal antibody preparation techniques and their applications}

To date, many relatively mature $\mathrm{mAb}$ preparation technologies, e.g. the hybridoma technique, the phage display technique, the transgenic mouse technique, the ribosome display technique, and single $\mathrm{B}$ cell antibody preparation techniques, can be selected depending on the characteristics of the desired antibody (Fig. 2).

\section{Hybridoma technique}

Development history. As the earliest technology used to produce mAbs, the hybridoma technique, also known as the lymphocytic hybridoma technique, is developed from somatic cell fusion technology, which enables the realisation of the large-scale preparation of the uniform murine mAbs (26). It was first invented by Köhler and Milstein in 1975 to produce hybridoma cells through the fusion of mouse myeloma cells and immunised animal spleen cells, which have the ability to reproduce endlessly and secrete highly specific antibodies that can recognise specific antigens-mAbs (21). As they did not choose to patent the hybridoma technique, it is allowed to be used in academia and the pharmaceutical industry, leading to potential future treatments for a range of diseases including tumours (36).

Advantages and disadvantages. Although antibodies produced by the hybridoma technique possess attractive advantages, such as good specificity, high purity and large-scale production (25), some defects of murine-derived antibodies remain unavoidable. On the one hand, the low affinity of murine mAbs to the Fc fragment on the immunocyte surface, can cause light antibody-dependent cell-mediated cytotoxicity (ADCC), resulting in a mild killing effect on tumour cells (37). In addition, the killing effect has a short time in which to take effect because of the short half-life of murine mAbs in the blood (38).

On the other hand, murine mAbs cause immunogenicity (39) and can further produce HAMA (27), which means that the repeated use of murine mAbs can lead to decreased efficiency and harm to humans due to allergic reactions (26). Additionally, it is not uncommon for patients treated with mAbs to produce human anti-murine immunoglobulin responses, possibly due to the immune deficiency associated with certain types of tumours (40). Therefore, some early murine mAbs, such as the E5 murine mAb, not only failed to achieve the desired effect in the treatment, but increased the mortality of patients, leading to a period of downturn in the development of $\mathrm{mAb}$ preparation and $\mathrm{mAb}$ treatment (41).

Clinical therapeutic applications. Rituximab, as the first lymphoma mAb developed in 1982, was shown to alleviate the condition of tumour patients, which raises great hope for the use of mAbs in tumour treatment (42). In addition, the first mAb drug, anti-cd3 mAb OKT3, was approved by the US FDA to enter the market in 1986; this mAb can alleviate the anti-rejection reaction during organ transplantation $(23,34)$. Overall, the $\mathrm{mAb}$ drugs produced at that time were murine $m A b s$ and rabbit mAbs, which have some clinical drawbacks (26). Recently, with the advances in technology, human hybridoma technology has been developed as a new mAb preparation technology on the basis of mouse hybridoma technology and rabbit hybridoma technology, which causes 

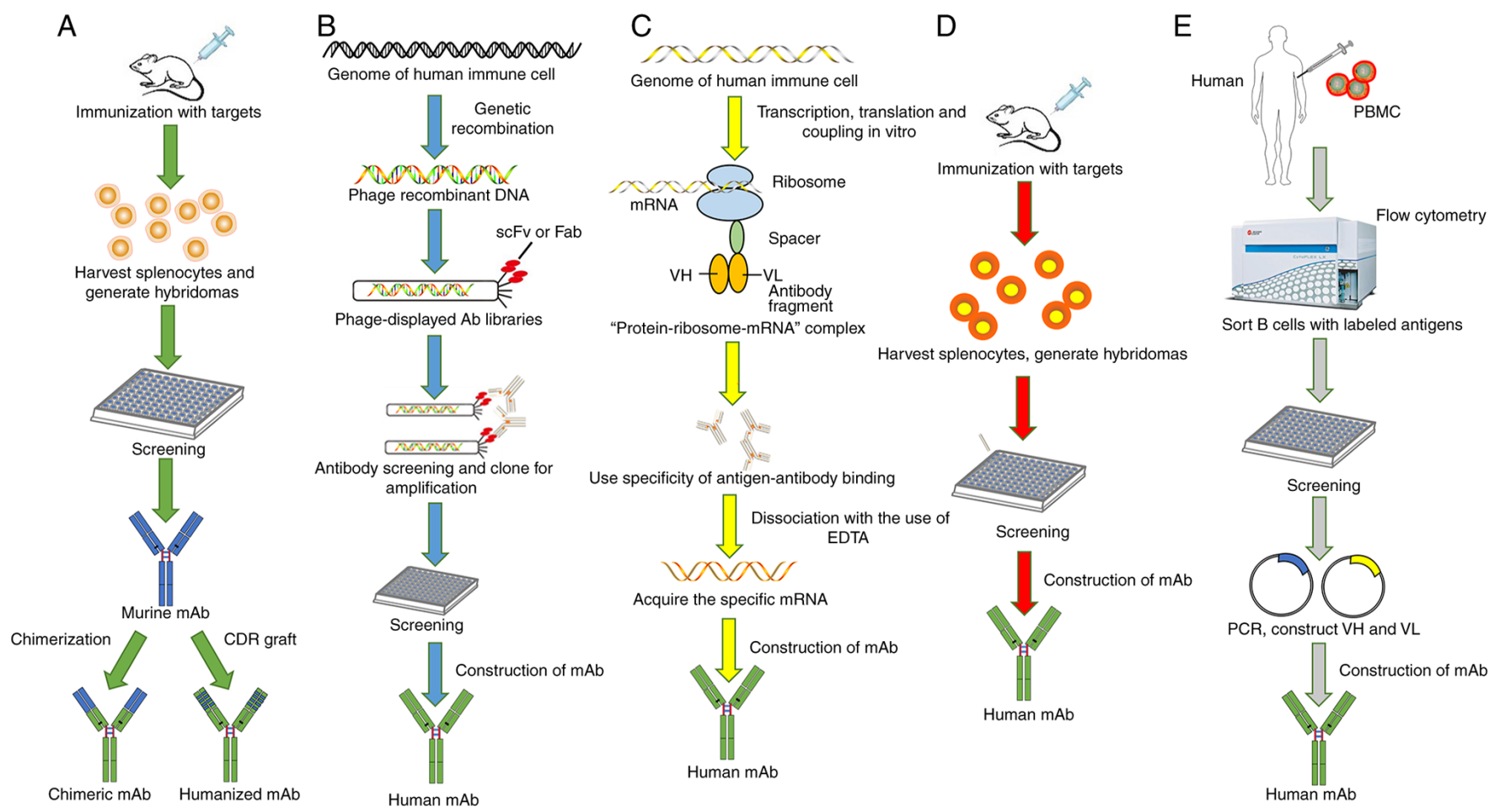

Figure 2. Approaches for the preparation of therapeutic monoclonal antibodies (mAbs). (A) Hybridoma technique. The traditional murine hybridoma technique starts by the immune response of mice triggered with the desired antigens. After that, splenocytes are harvested and fused with myeloma cells to produce hybridoma cells. After the screening, selected hybridoma cells are used to persistently generate chimeric or humanized monoclonal antibodies. (B) Phage display. A human phage-displayed antibody library is used to select the antigens of interest. After immuno-positive phage clones screened by ELISA and DNA sequences, construction of the mAb is made to help express humanized mAb. (C) Ribosome display. 'Protein-ribosome-mRNA' complex is constructed to help establish the Protein library of phage display by using specificity of antigen-antibody binding. Following dissociation with the use of EDTA, the acquired specific mRNA can help establish the DNA library of the specific antibody by RT-PCR, which expressed the specific humanized mAb with high affinity. (D) Transgenic mouse technique. Similar to the mouse hybridoma technique. (E) The single B cell technique. peripheral blood mononuclear cells (PBMCs) are prepared from infected or vaccinated donors so as to isolate suitable B cells by flow cytometry. After that, VH and VL information of each B cell informs the generation of human mAbs by RT-PCR.

the fusion of immunised human B cells and human myeloma cells to produce hybrid cells that can divide indefinitely and secrete antibodies (26). However, the technology has produced a very limited number of multiple myeloma cell lines, has a low cell fusion success rate and easily causes the loss of chromosomes (43).

\section{DNA recombinant antibody technique}

Development process. Advances in genetic engineering techniques facilitate the development of chimeric (murine/human) mAbs. With the use of DNA recombination technology, chimeric genes consisting of a combination of the Variable (V) region gene of murine antibodies and the Constant $(\mathrm{C})$ region gene of human antibodies, inserted into the expression vector containing the $\mathrm{C}$ region of human antibodies, is used to express chimeric $\mathrm{mAbs}$ which possess a humanised $\mathrm{C}$ region and heterogeneous $\mathrm{V}$ region. The resulting antibody (44) causes reduced immunogenicity of the allogenic antibody while retaining the ability of the parental antibody to specifically bind to the antigen. However, because there is still some residual immunogenicity in the FR of $\mathrm{V}$ region, HAMA may be induced (45). In view of this, primate antibodies produced by immunising macaques can be chosen as the heterologous antibody to chimerism with the $\mathrm{C}$ region, because the $\mathrm{V}$ region of primate antibodies show few differences to the $\mathrm{V}$ region of human antigens, thus decreasing the immunogenicity.
Advantages and disadvantages. Compared with murine mAbs prepared by the hybridoma technique which are limited in clinical application due to their ability to cause HAMA reactions in vivo, the chimeric mAbs prepared by DNA recombinant antibody technique can significantly alleviate adverse reactions because of an approximately $70 \%$ reduction in immunogenicity of the heterologous antibody, thus improving the curative effect (46). For example, infliximab is capable of preventing and reducing inflammation as the chimeric $\mathrm{mAb}$ to tumour necrosis factor (TNF)- $\alpha$ in the treatment of rheumatoid arthritis (RA) and Crohn's disease (47). In addition, it also has the effector functions of human antibodies because of the existence of a humanised $\mathrm{Fc}$ fraction, which makes the chimeric $\mathrm{mAb}$ possess more potent complement-dependent cytotoxicity (CDC) and ADCC (48). On the basis of the mechanism, the rituximab chimeric anti-CD20 mAb was developed to treat relapsed indolent lymphoma because the cell-surface antigen CD20 is expressed on more than $90 \%$ of B-cell lymphomas and chronic lymphocytic leukaemias (49). Abciximab, a Fab fragment of a chimeric mAb, functions as a GP IIb/IIIa receptor antagonist to significantly decrease the size of coronary artery aneurysms in children with Kawasaki disease by promoting vascular remodelling, and decrease the risk to go through early stent thrombosis in diabetic patients with ST-segment elevation myocardial infarction $(50,51)$. In addition, basiliximab and cetuximab, serving as chimeric $\mathrm{mAb}$, 
can function to prevent early acute or slow rejection reaction after organ or allogeneic hematopoietic stem cell transplantation so as to treat acute graft-vs. -host disease $(52,53)$, and treat different cancers including recurrent and metastatic head and neck squamous cell carcinoma and metastatic colorectal cancer $(54,55)$, respectively. However, chimeric antibodies can partially solve the problem of heterologous protein rejection, but they may still induce an HAMA reaction, interfere with antibody efficacy and induce a hypersensitivity reaction due to the fact that they also contain the murine $\mathrm{V}$ region which limits their clinical application to some extent $(56,57)$.

Phage display. Phage display techniques can clone the peptide-coding or protein-coding gene fragment into the appropriate position of the phage shell protein structure (58), so that the foreign polypeptide/protein and shell protein are expressed in the form of a fusion of each other and then displayed on the phage surface as the progeny phage reassembles $(59,60)$. The demonstrated polypeptide or protein can maintain a relatively independent spatial structure and biological activity, which is conducive to the recognition and binding of target molecules, providing a way to screen for single-chain antibodies with high specificity and binding ability (61). In theory, as long as enough of this type of peptide is expressed in the library, one or more phage can bind to these targets.

Development process. Phage display was pioneered by Greg Winter and his colleagues (59). In 1985, G.P. Smith developed phage display technology (62) based on the research of phage biology and molecular biology, which show unique advantages in virus infection, including HIV infection and tumour diagnosis and treatment. Later, in 1987, Geysen et al proposed that short peptides containing key amino acid residues can mimic the antigenic determinants of proteins and the interaction between proteins is achieved by the interaction between local peptides (63). In 1988, Parmley and Smith proposed the idea that the construction of a random peptide library could provide insight into the antigen-determining cluster epitopes recognised by antibodies (64). Subsequently, Scott and Smith fused random short peptides to the surface protein PIII of filamentous phage and displayed it on the surface of the phage, creating the first phage random peptide library (65). In the same year, McCafferty et al used phage display technology to screen for single-chain antibodies to lysozyme bacteria, propelling phage display technology into an era of widespread application (66). Recently, because of the pioneering work and application in the phage display of peptides and antibodies, Professors George P. Smith and Gregory P. Winter both won a quarter share of the 2018 Nobel Prize in Chemistry (59). Until now, the application scope of phage display technology has been expanding, and the technology has also been constantly improving and developing.

Advantages and disadvantages. The emergence of phage display technology has opened up a simple and fast route for the production of genetically engineered mAbs, which bypasses the technical difficulty of hybridomas (35). It clones and amplifies VH and VL gene fragments in human lymphocyte spectrum by RT-PCR, and randomly combines gene fragments into expression vectors, in order to construct a large-capacity human antibody library (27). In addition, the phage display can simplify the cloning process and acquire a large amount of material to produce peptides or proteins because of the small size of the phage genome and high efficiency of the phage infection $(67,68)$.

The phage display offers the direct physical link between a protein and its genetic material, which helps people to effectively screen the desired cloning again and again, and then amplify it (67). In the process of library screening, specific phage clones are enriched continuously due to their specific affinity for ligands, and relatively rare clones that can bind ligands can be quickly and effectively screened out from a large library (58). Therefore, the biggest advantage of phage display is that once the phage library is established, specific antibodies against the target antigen can be directly screened from the library according to the needs within 23 weeks, which greatly reduces the preparation cycle of mAbs (61). In addition, by specific construction, the filamentous phage may act as a vector, and generate a peptide library of phage display that contains hundreds of millions of unique peptides, which are conducive to their application in antiviral research (69). However, due to the different binding properties of antibodies in bacteria and eukaryotic cells, the applicability of the technology is limited to a certain extent (70). The processes of the phage display refer to bacterial transformation, phage packaging, and even transmembrane secretion processes, which limit the capacity of the phage display library and their molecular diversity. At present, the capacity of the phage display library is usually $10^{11}(27)$. Also, limited by the expression system, the antibody library is not large enough to support the acquisition of some rare antibodies and not all sequences are well expressed in phages, because the realisation of some protein functions acquire folding, transportation, membrane insertion and complexation, resulting in the need for additional selection pressure during in vivo screening (45). It is difficult to obtain antibodies that inhibit the growth or function of phages or the expression host, as the phage display system depends on the expression of intracellular genes, which may make the diversity of the library decrease rapidly (71). Also, a phage display library cannot take on the effective mutation and recombination in vitro, which in turn limits the genetic diversity of the molecules in the library $(72,73)$. Nevertheless, these temporary shortcomings cannot obscure the great potential of its applications.

Clinical therapeutic applications. Nowadays, with the establishment of more phage display libraries, the construction of advanced genetic operating system and the development of more efficient phage display systems, phage display technology plays an important role in different fields, especially in protein and antibody-related fields (34). Phage display technology has become an advantageous tool for detecting the protein spatial structure, exploring the binding sites between receptors and ligands, and searching for ligands with high affinity and biological activity (74). It has had a far-reaching impact on research into the mutual recognition of protein molecules, the preparation of phage-functionalised biosensors, the development of new vaccines and tumour therapy $(75,76)$. In addition, Humira, ramucirumab and other mAbs developed by phage display technology have been widely used in clinical practice, 
especially Humira, which is widely applied in the treatment of rheumatoid arthritis (RA), psoriatic arthritis, Crohn's disease, ankylosing spondylitis and uveitis (45).

\section{Transgenic animal technology}

Development process. Transgenic animal technology is mainly based on the idea of 'why can't mice be more like people'. It transfers human antibody loci into animals including mice, chickens and cows, and rearranges and re-expresses human antibody $\mathrm{V}$ region genes in their lymphocytes, so that transgenic animals can produce B lymphocytes which fully express human antibodies; this is essentially the partial humanisation of animals (77-79). Under the stimulation of antigens, these lymphocytes can be cloned and differentiated continuously to form plasma cells that are capable of producing high-affinity human antibodies (80). In addition, transgenic animals carrying human DNA fragments have complete functions, including effective homologous conversion and affinity maturation, which can produce high affinity human antibodies after the animals are immunised by any target antigen (37).

As early as 1985, the production of fully human antibodies using transgenic mice was first proposed by Alt et al (81). Later, many difficulties, including the large size of the human Ig loci, were followed but overcome one after another (82). In 1996 and 1997, Medarex and Abgenix successfully established the HuMab-Mouse ${ }^{\circledR}$ (Medarex), which significantly improved the efficiency of full human mAb production (83) and XenoMouse ${ }^{\mathrm{TM}}$ (Abgenix) $(84,85)$.

Advantages, disadvantages and clinical therapeutic applications. In the past three decades, transgenic animal technology through genetic engineering has been envisaged to improve food quality, animal production and the production of biological products, to reduce or minimise the environmental impact of animal production and to add value to animal products. Recently, with the advance of the ability for targeted genome engineering via genome editing methods such as TALENs, ZFN and the CRISPR/Cas9 system, this technique has been widely used to obtain a series of human mAbs against the interleukin-6 (IL-6) receptor, TNF receptor and epidermal growth factor receptor (EGFR), which play important roles in the treatment of tumours and other diseases $(86,87)$. mAbs against the human IL-6 receptor can show strong antitumour activity in vivo against multiple myeloma cells by inhibiting IL-6 functions (87). H-R3, as a humanised anti-EGFR antibody with antitumour, anti-proliferative, anti-angiogenic and pro-apoptotic properties, can act as an effective EGFR antagonist to inhibit signal transduction, in order to directly or indirectly affect cell proliferation, cell survival and angiogenesis-inducing capacity (88). As an important milestone in validating XenoMouse strains as well as other human immunoglobulin-producing mouse technologies, the first fully human $\mathrm{mAb}$, panitumumab, which was developed from XenoMouse technology and approved by a regulatory agency, has a positive risk-benefit profile in advanced, chemotherapy refractory colorectal tumours and has the potential to increase treatment rates of this disease in earlier lines of therapy (89). Recently, the first transgenic rabbit strain for human antibody production has been created with the discovery that the antibody diversification mechanism at work in rabbits can act on the fragments of the human transgenic immunoglobulin gene (90), which further expands the application of human mAbs in drug development and promises to lead to new treatments for various diseases.

Ribosome display technology. Ribosome display technology is a powerful tool for protein screening using functional protein interactions in vitro (91). By associating genotypes with protein phenotypes, it can use specific ligands of target proteins to select target proteins and corresponding gene sequences from the protein display library (92). It combines the correctly folded protein and its mRNA on the ribosome at the same time to form mRNA-ribosome-protein trimer, in order to screen some high-affinity proteins with specific binding to target molecules, including antibodies, peptides and enzymes $(93,94)$. The preparative technique involves different key processes, including specific processing and modification of the DNA that encodes proteins, transcription and translation, affinity screening in vitro, the separation of mRNA and molecular orientation evolution in vitro (95).

Development process. The ribosomal display technology has undergone a certain period of research from the time it was proposed to the time it was developed and matured. In 1994, Mattheakis et al of the Afflymax Institute in the US put the ideas of their predecessors into practice for the first time and established the prototype of ribosome display technology, which mainly used 'polypeptide-polyribosome-mRNA' complex to construct peptide libraries on polyribosomes, thus screening the polypeptide ligands of immobilized mAbs with an affinity constant of $10^{9}$ (Nmol level) from a peptide library with a capacity of $10^{12}(96)$. Later, Hanes and Plückthun improved the polyribosome display technology and established a new technology, ribosome display technology, in 1997, for the screening of complete functional proteins such as antibodies in vitro, on the basis of previous research results (93).

Advantages and disadvantages. Traditional screening techniques have insurmountable drawbacks, mainly related to cell transfection, phage packaging, transmembrane secretion and protein degradation in library construction and screening $(97,98)$. The library capacity and molecular diversity of phage or mRNA display technology are somewhat limited, which reduces the efficiency of library screening (71). In contrast, a ribosome display is a powerful way to screen large libraries and acquire molecular evolution $(99,100)$. It has the advantages of simple library construction, large library capacity, strong molecular diversity, simple screening methods and no need for selection pressure, and can even improve the affinity of target proteins by introducing mutation and recombination technology $(93,94)$. As a system to produce and screen folded proteins entirely in vitro, the ribosome display technique is shown to greatly exploit replicability of mRNA, allowing efficient enrichment of target genes, avoiding the step of bacterial transformation and making the technique unconstrained by the efficiency of cellular transformation (101). On the one hand, the technique greatly increases library capacity and screening throughput, and makes it easy to build a very large volume of antibody library (101). On the other hand, while the expressed proteins have the correct spatial fold conformation, the technique can be combined with 
some special PCR techniques to improve the protein expression diversity $(28,102,103)$. It also can be used for the screening and research of cytotoxic fractions (94).

However, there are still some technical problems that need to be further advanced. Undoubtedly, maintaining mRNA stability and preventing the degradation of mRNA is the first problem in a ribosome display system (28). Facing the problem, Yamaguchi et al reported a novel screening method-cDNA display, which prevents the degradation of mRNA by promoting the binding of mRNA to linkers and the reverse transcriptional synthesis of cDNA, thus converting mRNA-protein fusions to cDNA-protein fusions and avoiding problems due to the stability of mRNA (104). The use of modified nucleotides as substrates for transcription reactions can also stabilise mRNA (105). In addition, how to construct the more stable 'mRNA-ribosome-protein' complex was one of the problems (106), as it only occurs in cases where the complex is complicated but its stability is poor in practice due to ribosomal display. To solve the problem, Roberts and Szostak developed a simpler and more effective display system-mRNA display system, which allows mRNA to bind to its encoded polypeptide in the presence of puromycin to form a stable mRNA-peptide complex that screens for the target peptide (107). The anti-small stable RNA A (anti-SsrA) oligonucleotides were designed by Muranaka et al to inhibit the function of SsrA and obviously promote the form of the 'mRNA-ribosome-protein' complex (108). In addition, how to improve the display of large molecular protein in the ribosome is also a problem that needs to be solved.

Clinical therapeutic applications. At present, there are numerous reports on the preparation of human mAbs by ribosomal display technology, and the advantages of this technology represent the developmental direction of mAbs (28). On the one hand, it can be applied widely in antibody engineering, proteomics, epitope mapping, and synthetic enzymes $(93,103)$. On the other hand, it also opens up a new way to screen new therapeutic antibodies and new drugs for diagnosis and treatment in tumours, autoimmune diseases, infectious diseases, and inflammatory disorders (94). Ribosome display technology, as a new cloning display technology, will show a more extensive application space in protein interaction research, new drug development and proteomics $(95,109)$.

\section{A single B-cell monoclonal antibody generation technology} Development process. As early as 2003, Wardemann et al prepared autoreactive antibodies with the use of early human B-cell precursors isolated from the bone marrow, to examine the structure, development and silencing of autoreactive B cells (110). In 2004, Traggiai et al immortalised the isolated human memory B cell with EBV and screened 35 mAbs that were well neutralised against influenza virus, which makes it possible for memory B cells to produce mAbs (111). Since then, monoclonal B-cell technology for generating $\mathrm{mAbs}$ has been gradually applied to various experimental research and has made great contributions to the development of many fields of life science as an important tool for modern life science research.

Advantages and disadvantages. In recent years, single B-cell antibody preparation techniques have begun to spring up and have gradually become widely used, alongside the development of molecular cellular biology (112). This is because mAbs prepared by single B-cell antibody technology have the characteristics of full human origin, high specificity and uniformity, showing unique advantages and good application prospects in the treatment of pathogenic microbial infections, tumours, autoimmune diseases and organ transplantation $(113,114)$.

Compared with other $\mathrm{mAb}$ preparation techniques, monoclonal B-cell technology, is a technique for the cloning and expression of B-cell antibodies with single antigenic specificity in vitro, which preserves the natural pairing in the $\mathrm{V}$ region of the light and heavy chain, and has the advantages of good gene diversity, high efficiency, full humanisation and the small number of cells required (115). Studies have shown that human memory B cells can survive in humans for more than 50 years, providing a historical record of the specific antibodies produced during most of the host's lifetime (116). In contrast, antibodies in the body fluids used in most traditional methods usually decay after macroglobulin clearance, which means that people lose their protective antibody within a few years (117). In addition, it is proposed that memory B cells in the blood of virus-infected patients may store records of early infection with the virus in patients-the genes, which provide a new direction for the research and development of mAbs (118).

Therapeutic application in clinical. Currently, the preparation of memory B-cell antibodies has become a popular method used to prepare the humanised antibody, which also promotes immunological research including antibody affinity maturation, the defence mechanism against vaccine immunity, vaccine development, and the treatment of tumours and autoimmune diseases at the same time $(1,119)$. With the maturity and improvement of B-cell sorting technology, subsequent PCR gene amplification methods and the high-throughput analysis and identification of antibody genes, memory B-cell antibody preparation technology will play an unprecedented important role in the diagnosis, pharmacodynamic and clinical application in the future, leading to a new era of therapeutic antibody research (120-122). As this approach has also been successful in widely isolating neutralizing antibodies against viruses including SARS and H5N1 influenza, it can provide not only neutralizing antibodies for passive serum therapy, but also information for vaccine design, and is expected to accelerate the development of therapeutics in the field of infectious diseases $(119,123)$. Additionally, Wrammert et al produced anti-H1N1 antibodies in 2009 by isolating plasma cells from peripheral blood, to analyse the characteristics of antibodies in detail generated from plasma blasts induced by pandemic H1N1 infection (124).

\section{Application of monoclonal antibodies in tumour therapy}

Mechanisms of monoclonal antibodies as antitumour drugs. Traditionally, mAbs produce cytotoxic effects in tumour cells though ADCC, CDC, changing signal transduction, elimination of the cell-surface antigen, and targeted conveying payloads (125).

$A D C C$. In general, ADCC is achieved by the specific binding of mAbs and the targeted antigen of tumour cells (126). 
Namely, the Fc fraction of mAbs can bind to the receptor of immune effector cells (NK cells, macrophages, neutrophils, granulocytes), and achieve activation of intracellular signals in the next moment, resulting in ADCC $(126,127)$. NK cells activated by antibodies can release cellular cytotoxic granules (perforin and granzyme) to achieve cell apoptosis on the one hand, while they can release cytokines and chemokines to inhibit cell proliferation and angiogenesis on the other (128).

$C D C$. CDC refers to the cytotoxic effect involving complement; that is, after the binding of specific mAbs and the corresponding antigens on the surface of the cell membrane, the complex activates the classical pathway of complement and forms an attack membrane complex to induce a lysis effect on target cells $(127,129)$. It is worth noting that, although CDC does not directly preside over the antitumour effects of most mAbs, it produces a variety of factors that enhance $\operatorname{ADCC}(130,131)$.

Changing signal transduction. Almost every clinically effective unconjugated $\mathrm{mAb}$, directly or indirectly, interferes with the signal transduction that influences the proliferation and survival of targeted cell populations (132). Growth factor receptors are some of the most commonly targeted tumour-associated antigens whose activation under normal conditions induces mitotic reactions and promotes cell survival, are overexpressed in numerous malignancies, leading to promotion of tumour cell growth and insensitivity to chemotherapy drugs (133-135). Therefore, the use of mAbs is likely to normalise the cell growth rate and restore the sensitivity of cells to cytotoxic drugs by reducing the signal that passes through these receptors (136). For example, the pertuzumab block shows receptor heterodimerisation (the dimerisation of HER2 with HER3 and other HER family receptors) that is required for signal transduction to play an antitumour role $(130,137)$.

Application of monoclonal antibodies in molecular-targeted therapy. Targeted antitumour drugs provide a new concept concerning tumour therapy, referring to several tumour-associated signaling pathways and targets. For instance, the most common target antigens in solid tumours refer to epithelial cell adhesion molecule (Ep-CAM; also known as epithelial glycoprotein-2, EGP-2/GA 733-2), carcinoembryonic antigen (CEA), EGFR family including EGFR (also known as c-erbB-1), HER2/neu (c-erbB-2), HER3 (c-erbB-3) and HER4 (c-erbB-4) $(135,138,139)$. Compared with them, the mAbs applied in lymphoma usually target CD52, CD20, CD30, CD22, CD37 and CD79 $(135,136)$, with the easier achievement of a better effect because it is simpler to manage tumour penetration. In contrast to the above, tumour stroma and tumour vasculature offer some unique targets for antibody-based interaction because the new generation of tissue and vasculature show some components that differ from those in the normal situation, leading to the situation whereby fibroblast activation protein (FAP) (140) and tenascin-C (TNC) (141) are regarded as targets in the tumour stroma, Fibronectin ED-B (142) and prostate-specific membrane antigen (PSMA) (143) are regarded as targets in the tumour vasculature. In addition, ligands including vascular endothelial growth factor (VEGF) are thought to target cell-surface receptors expressed on tumour cells or their supporting tissue $(140,144)$.

Application of monoclonal antibodies in immune checkpoint therapy (ICI). The fight between the immune system and tumour cells is a long-term dynamic process, which has both positive and mutual influences (145). In the process whereby a healthy individual's immune cells detect and kill tumour cells via the antitumour immune response, activated $\mathrm{T}$ cells cause upregulated expression of several surface receptors, which can bind with relevant ligands expressed highly on the surface of tumour cells, resulting in inhibition of the immune response and downregulation of potent immune response (146). These surface receptors, namely the suppressive regulatory molecules, are essential for maintaining self-tolerance, preventing autoimmune response and minimizing tissue damage by regulating the time and intensity of the immune response; this is called the immune checkpoint $(146,147)$. The immune checkpoint results in the inhibition of cellular function, meaning that the body cannot produce an effective antitumour immune response, ultimately leading to immune escape of the tumour (148).

On the theoretical basis of the immune checkpoint, some mAbs have been developed as immune checkpoint inhibitors to block the interaction between tumour cells expressing immune checkpoints and immune cells, in order to block the inhibitory effect of tumour cells on immune cells $(148,149)$. During the occurrence and development of tumours, immune checkpoint inhibitors can enhance the immune function of the body and restore the recognition ability of $\mathrm{T}$ cells, in order to eliminate tumours or slow down the development of tumours $(150,151)$ (Fig. 3). Recently, tumour-related immune checkpoint molecules mainly include programmed death-1 (PD-1), cytotoxic T lymphocyte-associated antigen-4 (CTLA-4), T-cell immunoglobulin mucin 3 (TIM3) and lymphocyte activation gene-3 (LAG3) $(145,146,150)$.

Anti-CTLA-4. CTLA-4 (also known as CD152) is a transmembrane protein expressed on the surface of activated CD4 ${ }^{+}$ $\mathrm{T}$ cells, activated $\mathrm{CD}^{+} \mathrm{T}$ cells, and regulatory $\mathrm{T}$ cells (Treg cells), which can bind to the CD86(B7-2) and CD80(B7-1) ligand to negatively regulate $\mathrm{T}$-cell activation (152). In addition, there is an intracellular pool of CTLA-4 in recycling endosomes of Treg and memory $\mathrm{T}$ cells which can be rapidly cycled to the cell surface upon activation (153). Therefore, the anti-CTLA-4 mAb can decrease Treg cells and activate $\mathrm{T}$ cell immune response by terminating the activity of CTLA-4 (145). Ipilimumab is an mAb that blocks CTLA-4, which was approved by the FDA to treat melanoma in 2011 (150,154). The blocking effect of ipilimumab on CTLA-4 is, that Ipilimumab binds to CTLA-4 to further impede the interaction between CTLA-4 receptor and the B7 ligand, thus increasing the activation and proliferation of $\mathrm{T}$ cells (145). This means that the antitumour effect of ipilimumab on melanoma is indirect and the action mechanism may be to help the body's immune system recognize, target and attack melanoma cells (155). Hence, it is possible for ipilimumab to be used as a carrier of imaging agent with good targeting properties (156). In addition, it is reported that patients with human CTLA-4 insufficiency develop immune dysregulation, 


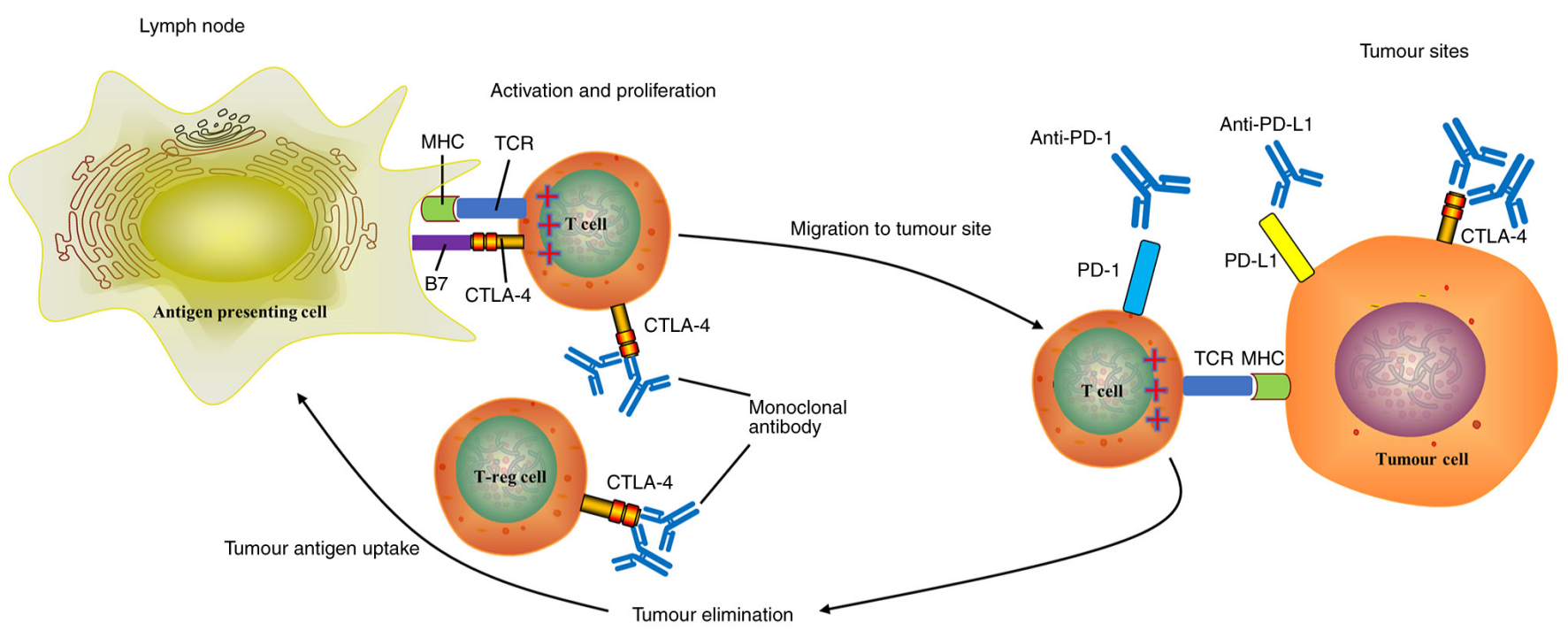

Figure 3. CTLA-4 and PD-1 pathway blockade in immune checkpoint therapy. CTLA-4 pathway blockade allows for activation and proliferation of more $\mathrm{T}$ cells, which can reduce Treg-mediated immunosuppression. PD-1 pathway blockade restores the activity of antitumor $\mathrm{T}$ cells that have become quiescent. A dual pathway blockade can take a synergistic effect, resulting in a more powerful and more lasting antitumor immune response. CTLA-4, cytotoxic T-lymphocyte-associated antigen 4; MHC, major histocompatibility complex; PD-1, programmed death 1; PD-L1, programmed death ligand 1; TCR, T-cell receptor; Treg, regulatory T cell.

lymphadenopathy and hepatosplenomegaly $(153,157,158)$. Therefore, anti-CTLA-4 mAbs should be able to inhibit the inhibitory signalling pathway and maintain the killing function of T cells, thereby killing tumour cells (146).

Although some anti-CTLA-4 mAbs do not cause an adverse reaction similar to cytotoxic drugs, including myelosuppression and alopecia, due to the different actions of cytotoxic drugs, they cause pathological damage to the body while producing an antitumour reaction, namely immune-related adverse events (IRAEs) $(146,149)$. Different from others, the toxicity profile of ipilimumab mainly manifests as symptoms associated with infusion, including rigor, pruritus, fatigue, nausea, dizziness, colitis, less frequently hypophysitis, hepatitis pneumonitis, and even hypotension, angioneurotic oedema, and dyspnoea (159-161). When facing the problems that occur in anti-CTLA-4 immunotherapy, combination therapy is put forward which may thereby provide greater antitumour activity than either agent alone by enhancing antitumour immune responses, and presenting a miraculous, unprecedented therapeutic effect (159). For example, in the treatment of progressive melanoma, the combined blocking of PD-1/PD-L1 and CTLA-4 can further improve efficacy in patients compared with the single blocking of PD-1/PD-L1 or CTLA-4 (162). Based on this, a trial involving patients with advanced melanoma was carried out and revealed that nivolumab plus ipilimumab provides the longer progression-free and overall survival, and better health-related quality of life than ipilimumab alone $(159,163)$. From another perspective, CTLA-4 inhibition can synergize with local chemotherapy, improving applicability and sensitivity to immune-checkpoint inhibition (164).

At present, not only ipilimumab, but also some other anti-CTLA-4 mAbs, have been optimised and developed, and have now attracted more and more attention from the public (148). Another anti-CTLA-4 mAb, tremelimumab, which was exploited by Pfizer, is being investigated in clinical trials (165). However, the research into tremelimumab has made little progress, meaning that ipilimumab is still regarded as the most promising anti-CTLA-4 mAb applied in tumour treatment (148).

Anti-PD-1 and anti-PD-L1. PD-1 (also known as CD279), as a member of the immunoglobulin superfamily which is mainly expressed on the surface of activated $\mathrm{T}$ cells, can be used as an immunosuppressive molecule to regulate the immune system and promote self-tolerance by downregulating the response of the immune system to human cells and suppressing the inflammatory activity of $\mathrm{T}$ cells, which may prevent the immune system from killing tumour cells $(166,167)$. PD-1 has at least two ligands, PD-L1 (also known as CD274 or B7-H1) and PD-L2 (CD273 or B7-DC) (146). In general, as one of the means by which human tissue protects them, PD-1 can bind with specific ligands on the immunocyte surface to prevent immune cells from activating and killing normal cells $(166,168)$. Additionally, the binding of PD-1 with ligands promotes the programmed death of $\mathrm{T}$ cells and reduces the apoptosis of regulatory $\mathrm{T}$ cells by suppressing the $\mathrm{T}$ cell activation signal primed by the interaction between MHC and TCR, in order to make the tumour cells acquire immune escape (146). Certain types of malignant tumours express a mass of PD- 1 on the cell surface; therefore, they evade the attack of immune cells by powerfully suppressing the activation of immune cells (129). PD-1 is also expressed on the surface of activated B cells and macrophages, indicating that PD-1 negatively regulates the immune response more widely than CTLA-4 (145). Therefore, immune regulation targeting of PD-1 plays an important role in antitumour, anti-infection, anti-autoimmune diseases and organ transplantation survival (169). Facing the situation, anti-PD-1 mAbs are manufactured as PD-1 inhibitors to activate the immune system to attack tumours and treat some types (145).

Compared with anti-CTLA-4 mAb therapy, immunotherapy with anti-PD-1 mAbs has a broader antitumour effect and fewer 
overall side effects $(170,171)$. The biggest difference between immune drugs and others is that it shows more persistent efficacy which could lead to long-term survival or even a clinical cure for patients with advanced disease (146). Currently, there are various drugs approved by the FDA, including nivolumab (also known as Opdivo) and pembrolizumab (also known as Keytruda) (172). The indications of nivolumab include melanoma, non-small cell lung cancer (NSCLC), renal cell carcinoma (RCC), classical Hodgkin's lymphoma (CHL), squamous cell carcinoma of the head and neck (SCCHN), and urothelial carcinoma (148). In contrast, pembrolizumab is mainly applied in melanoma, NSCLC, and SCCHN $(167,172)$.

At present, the anti-PD-1 mAbs are mostly used in combination therapies, because traditional therapy using anti-PD-1 $\mathrm{mAbs}$ alone can lead to various IRAEs, including fatigue, skin rash, colitis, hypophysitis, pneumonitis, myasthenia gravis and interstitial nephritis (171). For tumours that are highly dependent on the immunosuppressive mechanism of PD-1/PD-L1, such as malignant melanoma, Hodgkin's lymphoma, certain types of lung tumour, and colon tumours, it has shown remarkable efficacy (147), but for the vast majority of unselected solid tumours, the efficacy of PD-1 inhibitor alone is not high. In comparison, combination therapy improves the treatment effect and transforms patients who are not suitable for PD-1 inhibitor treatment into those who can benefit from it (173). First, the anti-PD-1 mAb can combine with another immunotherapy drug (174). A combination of the PD-1 and CTLA-4 $m A b s$ has been shown to be more effective in treating several tumours, including malignant melanoma, than either antibody alone (162). In addition, PD-1 can combine with anti-CTLA-4 or VEGF tyrosine kinase inhibitors (TKIs) to adjust first-line therapy for metastatic kidney carcinoma (175). Secondly, PD-1 in combination with chemotherapy is considered a promising treatment strategy (176). Chemotherapy has a profound impact on the antitumour immune by directly regulating immune cellular subsets or indirectly stimulating the immune system through the induction of immunogenic cell death, revealing the existence of synergy between cytotoxic chemotherapy and immune checkpoint inhibition (176). This combination therapy is also approved for the first-line treatment of advanced NSCLC (176). Nevertheless, there are some patients with chemotherapy-refractory metastatic solid tumours; for those patients, PD-1 inhibitor combined with radiotherapy is regarded as a salvage treatment $(177,178)$. This means that the anti-PD-1 may combine with radiotherapy to improve the overall survival (179). In addition, anti-PD-1 can combine with targeted drugs including acitinib, and levatinib $(180,181)$. Recent studies have shown that the association of acitinib with pembrolizumab provides improved clinical benefit in patients with previously untreated advanced renal cell carcinoma, which is well tolerated (182). In addition, the strategy of using anti-PD-1 mAbs in combination with oncolytic virus (OV) to enhance antitumour immunity and therapy has been developed (183). To validate this, research into the effect of IL-15-armed OV in combination with PD-1 inhibitors in mice with colon or ovarian carcinoma processes, has shown some results including tumour regression and the prolongation of overall survival (184). Moreover, a personalised mutanome vaccine can be used in combination therapy with anti-PD-1 $\mathrm{mAb}$ as it enhances the persistence of anti-PD-1-mediated effect and extends anti-PD-1 therapies to patients with no preexisting $\mathrm{T}$ cell response (185). Finally, the anti-PD-1 mAb can combine with novel tumour-specific immune cells, such as the chimeric antigen receptor T-cell (CAR-T), to produce better therapeutic effects (186). Some research has found that PD-1 blocks CAR-T cell therapy within solid tumours, therefore the anti-PD-1 mAb which prevents the PD-1-related inhibition of CAR-T cell response can increase the levels of cytolysis and cytokine secretion and enhance the in vivo antitumour function of CAR-T cells $(187,188)$.

PD-L1, expressed on the surface of tumour cells, can bind with PD-1 on the surface of activated $T$ cells and $B$ cells to conduct inhibitory signals and reduce $T$ cell proliferation $(146,189)$. As promising new agents, there are some anti-PD-L1 mAbs approved by the FDA in clinic, including atezolizumab (also known as Tecentriq) which is used to treat locally advanced or metastatic urothelial carcinoma, durvalumab (also known as Imfinzi) which is used to treat locally advanced or metastatic urothelial carcinoma and NSCLC, and avelumab (also known as Bavencio) which is used to treat meningioma, metastatic Merkel cell carcinoma and carcinoma of the urinary bladder $(128,167,190)$. In theory, compared with anti-PD-1 mAbs which bind to PD-L2, anti-PD-L1 mAbs have specific effects and demonstrate a certain superiority (146). The anti-PD-L1 mAbs can block the co-suppression of B7-1 and PD-1, which is conducive to fully activate the function of T cells and produce cytokines $(191,192)$. Therefore, anti-PD-L1 mAbs may more fully activate the immune system to kill tumours (191). Furthermore, it has been shown that durvalumab as a third-line or later treatment can significantly benefit advanced NSCLC patients with EGFR mutations or ALK rearrangements $\left(\mathrm{EGFR}^{+} / \mathrm{ALK}^{+}\right)$with $\geq 25 \%$ of tumour cells expressing PD-L1, although it is unsuitable for patients with $\mathrm{EGFR}^{+} / \mathrm{ALK}^{+}$to use the immune checkpoint inhibitor because of the low curative effect and subsequent severe adverse reactions (193). In summary, anti-PD-1 mAbs and anti-PD-L1 mAbs each have their own indications and application scope, and the combined utilisation can achieve mutual complementarity in the interest of our common development (146).

Others. In addition, there are various other useful checkpoints, such as the lymphocyte activation gene-3 (LAG-3), B7-H3, B7-H4, T cell immunoglobulin-3 (TIM-3), T cell immunoglobulin and ITIM domain protein (TIGIT), and V-domain immunoglobulin-containing suppressor of $\mathrm{T}$ cell activation (VISTA) (194-197), which are either entering the clinic or under active development.

\section{Potential combined therapeutic strategies}

Radioimmunotherapy, chemo-immunoconjugate and immunotoxin. In tumour-guided therapy, mAbs against tumour antigens are used in the guidance of chemotherapy drugs or radiotherapy drugs to the target organ, thereby directly killing the tumour cells or producing antibody-directed enzyme prodrug therapy (ADEPT) by specifically activating prodrugs within the tumour (198).

Radioimmunoconjugates. Radiation can act directly on DNA molecules and cause their damage, by ionising water 
molecules in living organisms to produce free radicals which break macromolecules and lead to cell damage (199). Based on this theory, mAbs with specific affinity for tumours can be utilised as a carrier of highly active radiopharmaceutical agents, thus forming radioimmunoconjugates that target tumour tissue to kill tumour cells or inhibit their growth while reducing radiation damage to normal tissue, using the ionising radiation effects of radioisotopes (11).

Chemo-immunoconjugate. The cytotoxic agent can conjugate with antitumour mAbs to form chemo-immunoconjugate, which can bind to the surface of antigen-positive tumour cells through the guidance of mAbs, inducing the internalisation of the conjugates (200). After that, these chemical drugs play their cytotoxic effects by binding to DNA molecules, thus killing tumour cells by inhibiting cell DNA and protein synthesis, interfering with cell nucleic acid or protein function, and inhibiting mitosis $(201,202)$. Common conjugates include cisplatin, cyclophosphamide, etoposide, adriamycin, paclitaxel, methotrexate, and vinblastine $(203,204)$.

Immunotoxin. Immunotoxin has a specific affinity for tumour cell surface antigens and can release bacterial or plant protein toxins to tumour cells without harming normal cells (205). Once the toxin enters the cell, it kills the tumour cell by inhibiting protein synthesis and altering signalling transmission (206). The main toxins currently used in reagents are diphtheria toxin, abrin, ricin, gelonin, and Pseudomonas aeruginosa endotoxin $(198,207,208)$.

Antibody-drug conjugates (ADCs). Antibody-based immunotherapy has been a major and rational therapeutic strategy in the clinical management of oncology $(209,210)$. In clinical practice, therapeutic $m$ Abs have a limited effectiveness in the treatment of solid tumours due to their large molecular weight, but a high degree of targeting (198). With a few exceptions such as mAbs to HER2, EGFR and CD20, most mAbs can bind with effector molecules by using specific linkers to produce antibody-drug conjugates (ADCs), which expand the scope of medical treatment while possessing highly targeted selection, achieving the complementary advantages of the two therapeutic drugs, which have little antitumour effects after binding the target antigen $(15,198)$. In contrast, small molecule chemicals are highly effective against tumour cells, in spite of the fact that they are less selective and may cause serious side effects, accidentally injuring normal cells due to off-target toxicity (211). Therefore, mAbs can bind with effector molecules by using specific linkers to produce ADCs, which expand the scope of medical treatment while owning highly targeted selection, achieving the complementary advantages of the two therapeutic drugs $(17,135)$. The mAbs can bind with effector molecules by using specific linkers to produce ADCs, which expand the scope of medical treatment while possessing highly targeted selection, achieving the complementary advantages of the two therapeutic drugs that can usually target tumour-associated antigens or specific receptors on the surface of tumour cells and show a selective directing effect on tumour cells (135). The effector molecules that act as payloads which produce a killing effect on tumours include radiopharmaceutical agents, cytotoxic agents and bacterial or plant protein toxins, conjugating respectively with mAbs to form radioimmunoconjugates, chemo-immunoconjugates and immunotoxins used in tumour-guided therapy (198). Currently, ADCs that have been approved by the FDA include brentuximab vedotin, trastuzumab emtansine, gemtuzumab ozogamicin, Inotuzumab ozogamicin, and polatuzumab vedotin $(211,212)$.

Action mechanism. Generally, ADCs are injected intravenously into the blood system to prevent the hydrolysis of mAbs by gastric acid and protease and are distributed into the tumour tissue by exosmosis of the endothelial pores and the endocytosis of endothelial cells (198). After the mAbs specifically direct drugs to the surface of tumour cells expressing tumour-specific antigens, ADCs come into tumour cells by internalisation $(211,213)$. As a general rule, there are three distinguished pathways to internalise, including clathrin-mediated endocytosis, caveolae-mediated endocytosis and pinocytosis (211). Later, with the influence of the acidic environment of the cytoplasm, some ADCs with cleavable linkers release effector molecules which can damage tumour cells, while other ADCs undergo the enzymatic fracture of linkers or $\mathrm{mAb}$ degradation with the influence of lysosomal protease (214). Finally, payload and degradation products are released into the cytoplasm of tumour cells, disturbing their cellular action mechanism, affecting the tumour microenvironment and inducing the death of cells (213). As ADCs are formed from maytansinoid drugs which are derivatives of maytansine and huC242, humanised $\mathrm{mAbs}$ which bind to the CanAg antigen expressed on colorectal tumours, pancreatic tumours and certain NSCLCs, huC242-maytansinoid conjugates can be disintegrated with the influence of lysosomal acidic conditions in order to release the maytansinoid, which contributes greatly to the antitumour effect of conjugates and the bystander effect (214). If the released payload is permeable, a bystander effect is produced, which means that the internalised payload enters and kills adjacent tumour cells, showing the effect of apoptotic tumour cells on bystander tumour cells (215). Although ADCs cannot directly kill the adjacent antigen-negative tumour cells, they can kill the antigen-positive tumour cells in order to indirectly kill the adjacent tumour cells by the bystander effect (216). Not only do ADCs damage the growing tumour, they can also disrupt the structure supporting tumour growth, such as tumour stromal cells and tumour vessels, in order to enhance the antitumour effect (217). More importantly, it was proposed that the activation of bystander effects by apoptotic tumour cells may be crucial to achieving the permanent eradication of tumours (215).

Basic strategies for selecting monoclonal antibodies. As an important part of ADCs, mAbs used in tumour-guided therapy must have some special characteristics. First, the ideal mAb must effectively bind to antigens on target cells so that the cytotoxic drugs are concentrated at the site of the tumour (212). Secondly, the mAbs should bind selectively to tumour cells and have little cross-reactivity with normal cells (212). If the antibody selectivity is poor or the selected antigen is present in normal tissues, cytotoxic drugs will be delivered to normal cells, resulting in targeted toxicity including allergic reactions, rashes and alopecia $(218,219)$. In addition, the Fc fractions of some mAbs 


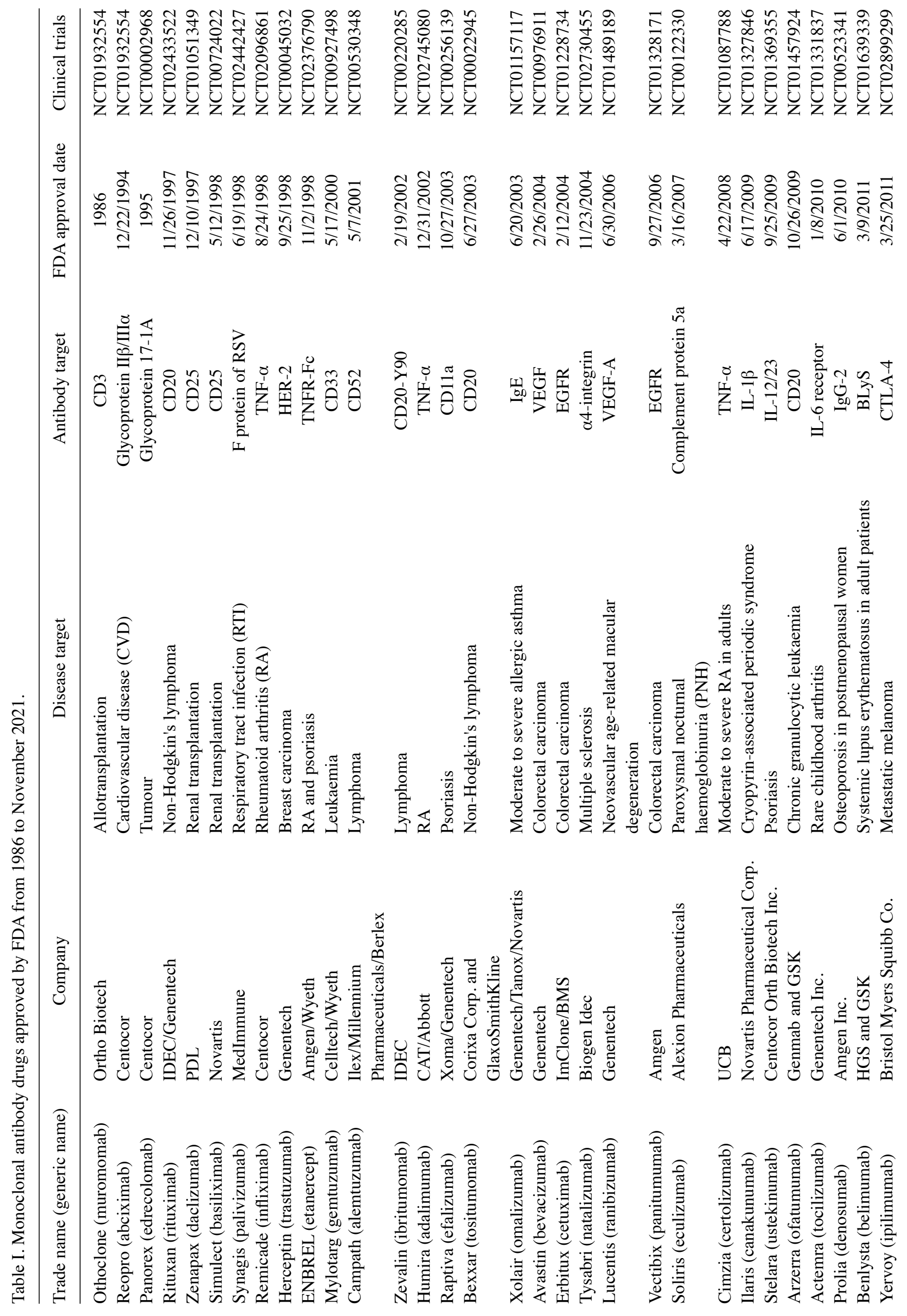




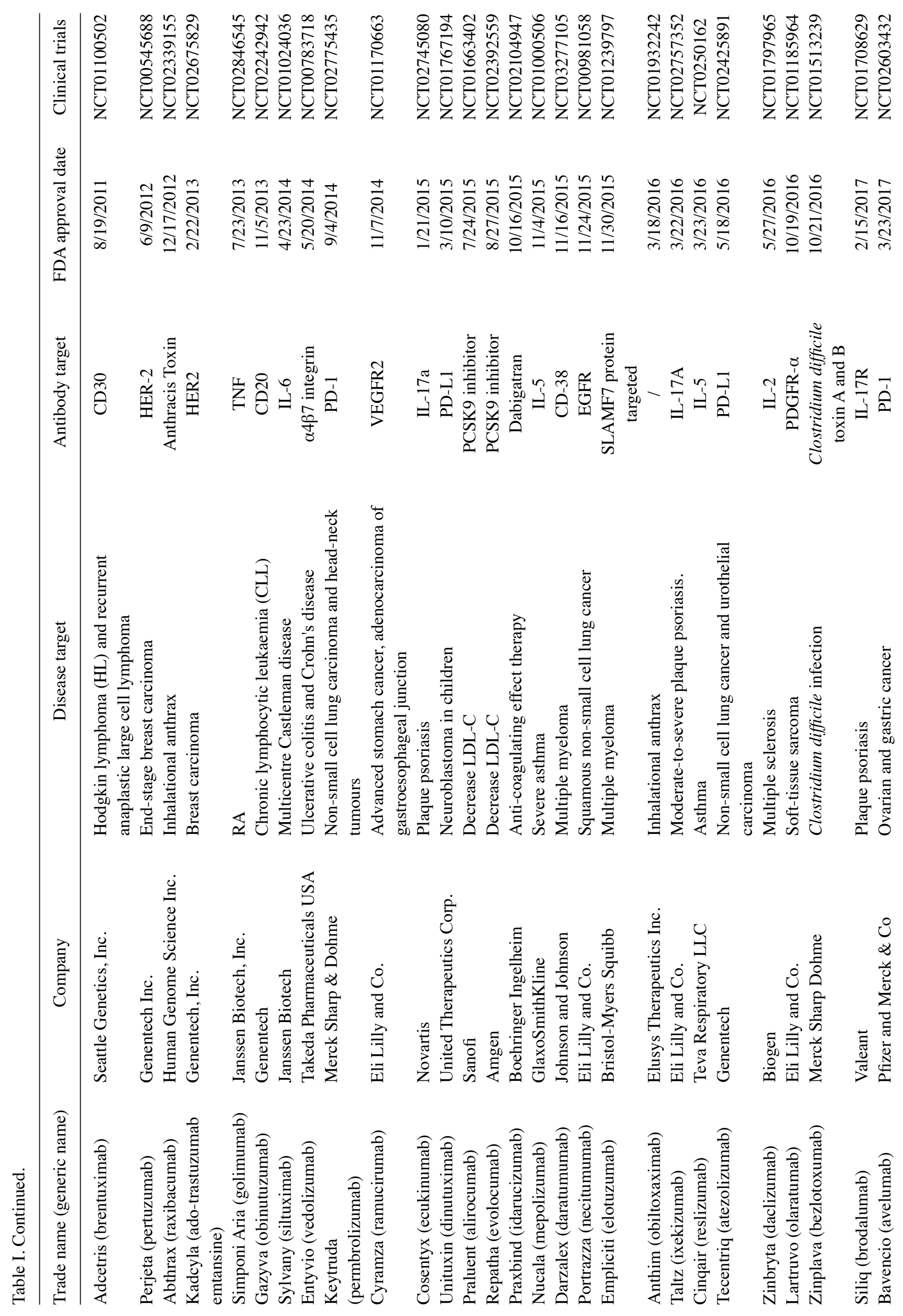




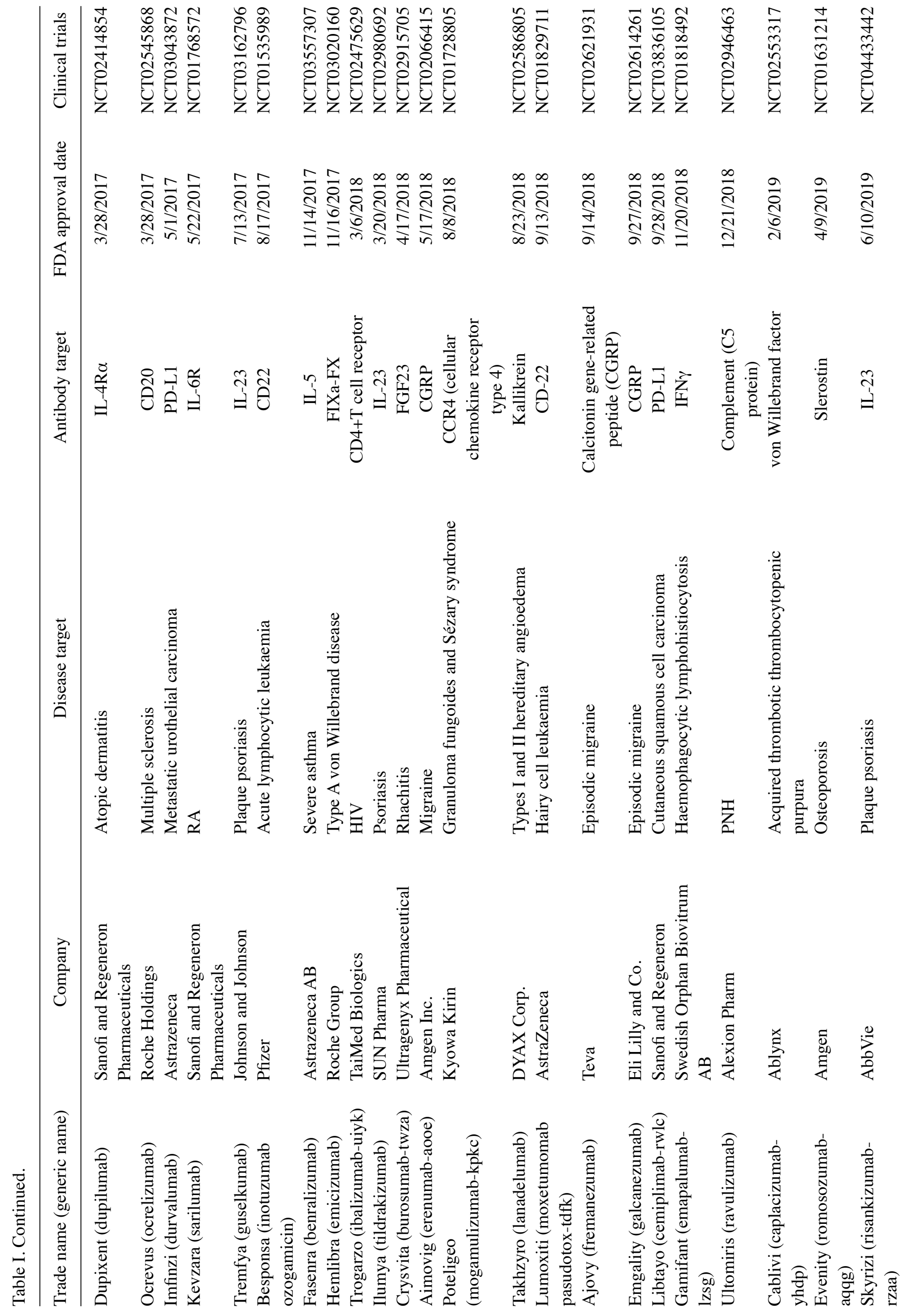




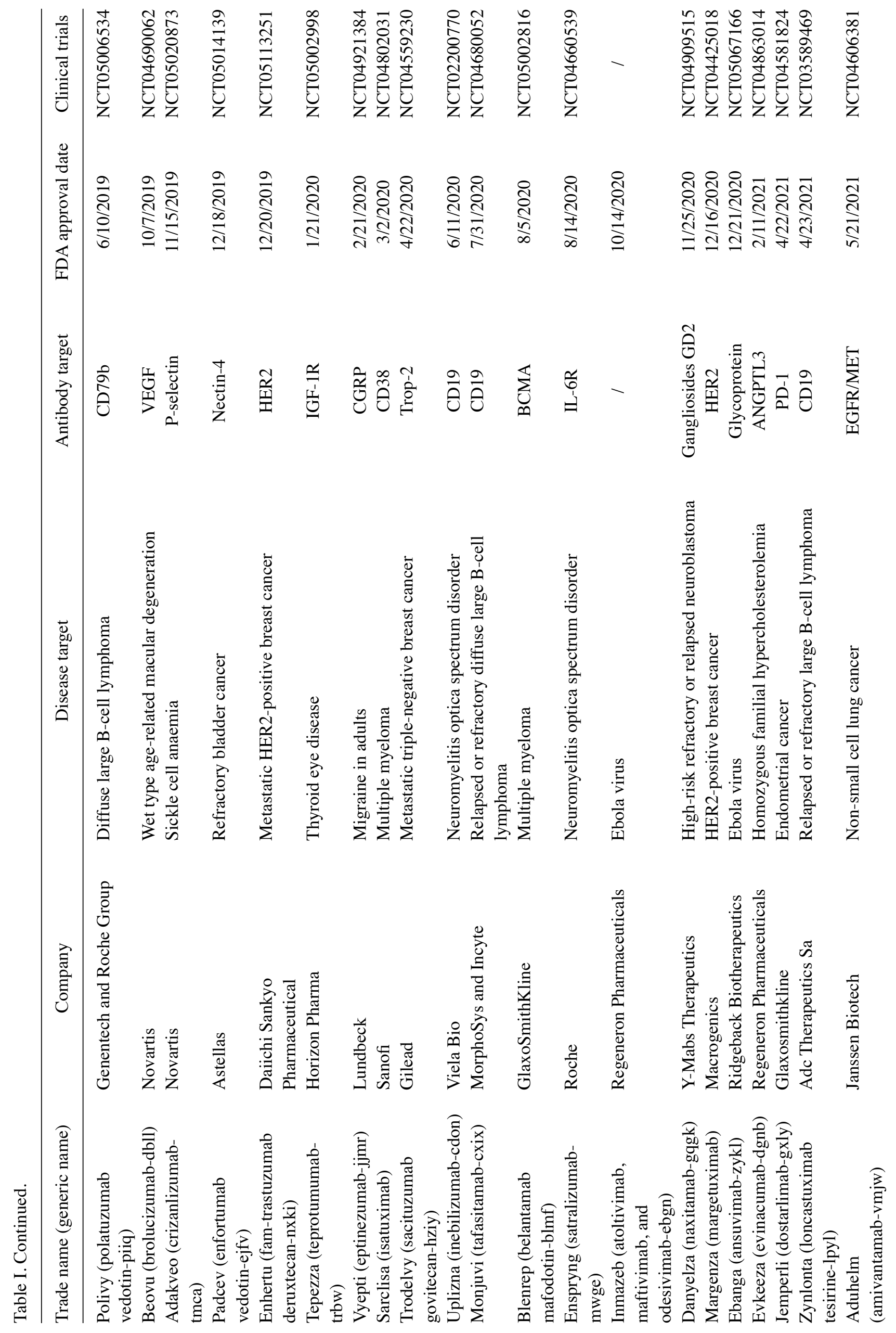


should have the affinity to bind with the Fc receptor of immune cells, thereby activating the killer effect of immunocytes (211). Thirdly, mAbs must own the ability to induce the internalisation of tumour cells, resulting in the release of the payload in the cytoplasm (220). In this way, the cytotoxic molecule can be released to extend the extent of damage to tumour cells, while mAbs play a certain antitumour role (212). Fourth, mAbs should be optimised to significantly reduce the non-specific binding of ADC drugs and prolong the half-life of ADCs in the blood (221). The immune interaction of the constant Fc fragment of an ADC is one of the major determinants of its cyclic half-life (222). As a consequence, humanised mAbs and fully human mAbs should be selected and the Fc fraction should be modified to decrease a part of immunogenicity and immunotoxicity and increase the cyclic half-life (223). Fifth, the molecular weight of mAbs should be appropriate. If the molecular weight is too large, ADCs will have difficulty penetrating the capillary endodermis and extracellular spaces (217). If the molecular weight is too small, the half-life will be influenced (224). Finally, the mAbs of ADCs should have some of the function of mAbs, including ADCC and CDC (217), which means that the mAb alone can be seen as an effective drug.

Nowadays, all ADCs in clinical trials use IgG because the biomolecule not only contains multiple natural sites for conjugation, but can also be modified to produce other conjugate sites (225). Due to their high affinity to target antigens and long circulating half-life in the blood, IgG can accumulate in the tumour region (226). Also, compared with others, IgG1 is most often chosen as the antibody part of ADCs (211). Generally, different IgG subtypes have different immune functions including ADCC and CDC (217). Compared with IgG4 and IgG2 subtypes, human IgG1 and IgG3 have stronger ADCC and CDC (217,227). Furthermore, IgG3 antibodies have a short half-life and rapid clearance compared to $\operatorname{IgG} 1, \mathrm{IgG} 2$ and $\mathrm{IgG} 4$, making them impossible to use in ADC synthesis (223). As a result, IgG1 is being used more selectively for ADC development.

In the research of tumour treatments, the development of fully human mAbs is very important, as murine mAbs and chimeric mAbs induce the immunogenicity of allogenic antibodies which can cause allergic reactions in humans (212). In early studies, the use of murine mAbs often triggered a severe immune response in humans, and patients produced human anti-murine antibodies which greatly reduced the therapeutic effect (228). Therefore, it is necessary to develop an $\mathrm{mAb}$ preparation technique, in order to make it possible to use better humanised or fully human mAbs as an essential component in an ADC in the future.

Near-infrared photoimmunotherapy (NIR-PIT). Traditional tumour treatments, such as surgery, chemotherapy, radiation therapy and photodynamic therapy (PDT), often damage the function of normal cells while killing diseased tissue; this can break the delicate balance between the pathogen tissue and the surrounding healthy cells (229). For example, after the photosensitiser is administered and enriched in the tumour, the PDT uses certain wavelengths of visible light to activate the photosensitiser, generating singlet oxygen to kill the tumour cells, in order to achieve a therapeutic effect (230). In the process, it is inevitable to damage normal tissues or organs because of the accumulation of photosensitisers in normal cells (231). In contrast, NIR-PIT, as a molecularly targeted phototherapy with 
Table II. Monoclonal antibody drug of global drug sales TOP100 in 2020.

\begin{tabular}{|c|c|c|c|c|}
\hline Ranking & Drug & Sale (billion dollars) & Manufacturer & Adaptation disease \\
\hline 1 & Humria $^{\circledR}$ (adalimumab) & 19.832 & Abbvie & Autoimmune disease \\
\hline 2 & Keytruda $^{\circledR}$ (pablizumab) & 14.38 & MRK & $\begin{array}{l}\text { Melanoma and non-small lung cancer } \\
\text { (NSCLC) }\end{array}$ \\
\hline 7 & Opdivo $^{\circledR}$ (nivolumab) & 7.81 & $\begin{array}{l}\text { Bristol-Myers } \\
\text { Squibb }\end{array}$ & Melanoma and NSCLC \\
\hline 8 & Stelara $^{\circledR}$ (ustekinumab) & 7.707 & $\begin{array}{l}\text { Johnson \& } \\
\text { Johnson (J\&J) }\end{array}$ & Psoriasis \\
\hline 14 & Avastin $^{\circledR}$ (bevacizumab) & 5.321 & Roche & Cancers including colon cancer \\
\hline 16 & Ocrevus $^{\circledR}$ (ocrelizumab) & 4.611 & Roche & Multiple sclerosis (MS) \\
\hline 18 & Darzalex $^{\circledR}$ (daratumumab) & 4.19 & $\mathrm{~J} \& \mathrm{~J}$ & Multiple myeloma \\
\hline 19 & Perjeta $^{\circledR}$ (pertuzumab) & 4.139 & Roche & Breast carcinoma \\
\hline 20 & Remicade $^{\circledR}$ (infliximab) & 4.077 & $\mathrm{~J} \& \mathrm{~J} / \mathrm{MSD}$ & Autoimmune disease \\
\hline 21 & Soliris $^{\circledR}$ (eculizumab) & 4.064 & Alexion & Paroxysmal nocturnal haemoglobinuria (PNH) \\
\hline 22 & Dupixent $^{\circledR}$ (dupilumab) & 4.045 & Sanofi & Atopic dermatitis \\
\hline 23 & Cosentyx ${ }^{\circledR}$ (secukinumab) & 3.995 & Novartis & Psoriasis \\
\hline 25 & Herceptin $^{\circledR}$ (trastuzumab) & 3.978 & Roche & Cancers including breast carcinoma \\
\hline 31 & Lucentis ${ }^{\circledR}$ (ranibizumab) & 3.473 & Roche/Novartis & Age-related macular degeneration (ARMD) \\
\hline 32 & $\operatorname{Rituxan}^{\circledR}$ (rituximab) & 3.418 & Roche & Leukaemia \\
\hline 35 & Xolain $^{\circledR}$ (omalizumab) & 3.281 & Roche/Novartis & Asthma \\
\hline 37 & Entyvio $^{\circledR}$ (vedolizumab) & 3.252 & Takeda & Ulcerative enteritis and Crohn's disease \\
\hline 42 & Actemra $^{\circledR}$ (tocilizumab) & 3.05 & Roche & Autoimmune disease \\
\hline 46 & Tecentriq $^{\circledR}$ (atezolizumab) & 2.919 & Roche & Metastatic urothelial carcinoma \\
\hline 50 & Prolia $^{\circledR} /$ Xgeva $^{\circledR}$ (denosumab) & 2.763 & $\begin{array}{l}\text { Amgen/Daiichi } \\
\text { Sankyo }\end{array}$ & Osteoporosis \\
\hline 61 & Hemlibra ${ }^{\circledR}$ (emicizumab) & 2.335 & Roche & Haemophilia \\
\hline 65 & Simponi ${ }^{\circledR}$ (golimumab) & 2.243 & $\mathrm{~J} \& \mathrm{~J}$ & Autoimmune disease \\
\hline 69 & Cimzia $^{\circledR}$ (certolizumab) & 1.887 & UCB & Autoimmune disease \\
\hline 72 & Imfinzi $^{\circledR}$ (durvalumab) & 2.042 & AstraZeneca & Lung cancer \\
\hline 78 & Tysabri ${ }^{\circledR}$ (natalizumab) & 1.946 & Biogen & MS \\
\hline 79 & Xgeva $^{\circledR}$ (denosumab) & 1.935 & Amgen & Giant cell tumour \\
\hline 82 & $\begin{array}{l}\text { Kadcyla }^{\circledR} \text { (ado-trastuzumab } \\
\text { emtansine) }\end{array}$ & 1.445 & Roche & Her2-positive metastatic breast cancer \\
\hline 84 & Taltz $^{\circledR}$ (ixekizumab) & 1.788 & $\begin{array}{l}\text { Eli Lilly and } \\
\text { Co. (LLY) }\end{array}$ & Plaque psoriasis \\
\hline 90 & Yervoy $^{\circledR}$ (ipilimumab) & 1.682 & $\begin{array}{l}\text { Bristol-Myers } \\
\text { Squibb }\end{array}$ & Melanoma and NSCLC \\
\hline 98 & Erbitux $^{\circledR}$ (cetuximab) & 1.552 & LLY/Merck & Colorectal tumour \\
\hline
\end{tabular}

the selective killing of diseased tissue developed on the basis of photodynamic therapy and immunotherapy, uses mAbs to direct the near-infrared, water-soluble, silicon-phthalocyanine derivative, IRdye700DX(IR700), to tumour sites, solving the problem of the low selectivity of photodynamic therapy $(229,232)$.

As early as the beginning of the 1980 s, Mew et al started studying PIT in vitro and in vivo, indicating that photo-immunoconjugates show higher selectivity to tumour tissues than photosensitisers or mAbs alone $(233,234)$. In subsequent years, although various photosensitisers, cross-linking methods and mAbs were developed and applied to photoimmunotherapy (PIT), the application of photo-immunoconjugate was still limited in vivo due to the hydrophobic nature of the photosensitisers (235). Later, a new type of PIT was developed in 2011 by Mitsunaga et al, NIR-PIT, which uses a target-specific photosensitiser based on NIR phthalocyanine dye, IR700, in combination with mAb targeting EGFR (236). In this treatment, mAb-IR700 conjugate binds to tumour cells that overexpress antibody targets (235). When irradiated with near-infrared light, IR700 in the conjugate is activated and rapidly destroys the hydrophobic tumour cell membrane, resulting in the death of the cancer cells $(229,237)$. In addition, the conjugate in vivo can indirectly activate cytotoxic T cells to kill tumours and inhibit tumour metastasis and recurrence by targeting CD44, CD133 and other tumour stem cell biomarkers $(229,232)$. 
In short, mAbs, as a specialised tool for identifying specific proteins on the surface of cancer cells, can act as a carrier to selectively deliver the photosensitisers which have a poor targeting ability to the tumour site, helping photosensitisers to locate and attach to cancer cells (238). More importantly, photoimmunotherapy could be applied to a range of cancers simply by altering $\mathrm{mAbs}$ in photo-immunoconjugates which have different targets, such as EGFR, HER2, PSMA, CD25, CEA, mesothelin, GPC3, CD47, CD20 and PD-L1 (139,229,238). Therefore, it is necessary to design and manufacture $\mathrm{mAbs}$ with better properties so that the PIT has a greater prospect.

\section{Monoclonal antibody drugs and the market value}

To date, biotechnology medicines have been developing rapidly, and half of the pharmaceuticals are synthesised by biotechnology companies around the world, especially those drugs with complex molecular structures including multi-specific drugs; this is because biotechnology is simpler than chemical synthesis and can produce higher economic efficiency (239). Therefore, as important components of biotechnology medicines, mAb drugs produced by lymphocyte hybridoma technology or genetic engineering technology, among others, have been widely used in the medical and biological fields as diagnostic and treatment agents in the last 30 years $(24,240)$. From the perspective of the ingredients of mAbs, these drugs can be divided into four generations: a) Murine-derived mAb drugs (-momab); b) human-murine chimeric mAb drugs (-ximab); c) humanised mAb drugs (-zumab); and d) fully human mAb drugs (-mumab) (29).

According to the investigative report of the American Pharmaceutical Research and Producers Association, the antibody drugs currently under development and already on the market are summarised as follows. To date, the FDA has approved $108 \mathrm{mAb}$ drugs, which have made a breakthrough in tumour immunotherapy and greatly improved the survival of patients with certain types of tumours and other diseases $(24,39)$ (Table I). From the perspective of diseases, tumours, and autoimmune, infectious, endocrine, cardiovascular and neurological diseases are the six sectors with the largest market size, all worth billions of dollars $(24,58)$ (Table II). In summary, mAbs have become a new force that cannot be ignored in biological drugs at present, and it will be the main force in the field of biomedicine in the future (239).

\section{Prospects}

In the past 30 years, from murine-derived mAbs to fully human mAbs, the preparation of $m A b s$ has made great progress. The research into human antibodies has made a breakthrough in the last 10 years, which has played an important role in medicine. Nowadays, mAbs are mainly used in the treatment of tumours, organ transplant rejection, autoimmune diseases and other diseases. Because of their good targeting, mAbs have a quick effect, small side effects and good effects. They are taking an increasing share in the sales of biotechnology drugs and have broad development prospects. However, the mature affinity of antibodies, the stability of antibodies secreted by human hybrid tumour cells and the mass production of antibodies still need to be solved.

With the development of the human genome project, the high specificity of mAbs has meant that they will play an irreplaceable role in the in-depth study of the subtle structure of proteins. Additionally, the emergence of phage display technology and ribosome display technology has greatly shortened the preparation cycle of $\mathrm{mAbs}$ and reduced their production costs. In addition, the safety of fully human mAbs has greatly promoted their wide application in the clinical treatment of infectious diseases, tumours, organ transplantation, haematological diseases, toxic diseases, allergic diseases, autoimmune diseases and other aspects. It is believed that with the development of molecular biology technology, especially the murine antibody humanisation technology, antibody library technology and transgenic technology, the clinical application of mAbs will become more extensive.

\section{Acknowledgements}

Not applicable.

\section{Funding}

This work was supported by grants from the National Natural Science Foundation of China (no. 82060638) and 'Double 10-Thousand Plan' of Jiangxi Province (Innovation and Technology Professionals as the High-End Talent).

\section{Availability of data and materials}

Not applicable.

\section{Authors' contributions}

TC and ZL provided the concepts of this review and designed its framework. JL and JD conducted the research, selected the literature findings and wrote the manuscript. All authors edited the manuscript. All authors read and approved the final manuscript for publication.

\section{Ethics approval and consent to participate}

Not applicable.

\section{Patient consent for publication}

Not applicable.

\section{Competing interests}

All authors declare that they have no competing interests.

\section{References}

1. Patel A: Benign vs malignant tumors. JAMA Oncol 6: 1488, 2020.

2. Murray PG and Young LS: An etiological role for the Epstein-Barr virus in the pathogenesis of classical Hodgkin lymphoma. Blood 134: 591-596, 2019.

3. Keum N and Giovannucci E: Global burden of colorectal cancer: Emerging trends, risk factors and prevention strategies. Nat Rev Gastroenterol Hepatol 16: 713-732, 2019.

4. Hasanpourghadi M, Pandurangan AK and Mustafa MR: Modulation of oncogenic transcription factors by bioactive natural products in breast cancer. Pharmacol Res 128: 376-388, 2018.

5. Stark A, Donahue TR, Reber HA and Hines OJ: Pancreatic cyst disease: A review. JAMA 315: 1882-1893, 2016. 
6. Travis WD, Asamura H, Bankier AA, Beasley MB, Detterbeck F, Flieder DB, Goo JM, MacMahon H, Naidich D, Nicholson AG, et al: The IASLC lung cancer staging project: Proposals for coding $\mathrm{T}$ categories for subsolid nodules and assessment of tumor size in part-solid tumors in the forthcoming eighth edition of the TNM classification of lung cancer. J Thorac Oncol 11: 1204-1223, 2016.

7. Clara-Trujillo S, Gallego Ferrer G and Gómez Ribelles JL: In vitro modeling of non-solid tumors: How far can tissue engineering go? Int J Mol Sci 21: 5747, 2020.

8. Shimada A: Hematological malignancies and molecular targeting therapy. Eur J Pharmacol 862: 172641, 2019.

9. Dunn-Pirio AM and Vlahovic G: Immunotherapy approaches in the treatment of malignant brain tumors. Cancer 123: 734-750, 2017.

10. Cassetta L and Pollard JW: Targeting macrophages: Therapeutic approaches in cancer. Nat Rev Drug Discov 17: 887-904, 2018.

11. Schweizer C, Schubert P, Rutzner S, Eckstein M, Haderlein M, Lettmaier S, Semrau S, Gostian AO, Frey B, Gaipl US, et al: Prospective evaluation of the prognostic value of immune-related adverse events in patients with non-melanoma solid tumour treated with PD-1/PD-L1 inhibitors alone and in combination with radiotherapy. Eur J Cancer 140: 55-62, 2020.

12. Ovacik $\mathrm{M}$ and Lin $\mathrm{K}$ : Tutorial on monoclonal antibody pharmacokinetics and its considerations in early development. Clin Transl Sci 11: 540-552, 2018

13. Cymer F, Beck H, Rohde A and Reusch D: Therapeutic monoclonal antibody $\mathrm{N}$-glycosylation-structure, function and therapeutic potential. Biologicals 52: 1-11, 2018.

14. Alkan SS: Legends of allergy/immunology: Georges Köhler and the discovery of MONOCLONAL antibodies. Allergy 74 $1412-1414,2019$.

15. Seaman S, Zhu Z, Saha S, Zhang XM, Yang MY, Hilton MB, Morris K, Szot C, Morris H, Swing DA, et al: Eradication of tumors through simultaneous ablation of CD276/B7-H3-positive tumor cells and tumor vasculature. Cancer Cell 31: 501-515.e8, 2017.

16. Fay EK and Graff JN: Immunotherapy in prostate cancer. Cancers (Basel) 12: 1752, 2020.

17. Arlotta KJ and Owen SC: Antibody and antibody derivatives as cancer therapeutics. Wiley Interdiscip Rev Nanomed Nanobiotechnol 11: e1556, 2019.

18. Starr CG and Tessier PM: Selecting and engineering monoclonal antibodies with drug-like specificity. Curr Opin Biotechnol 60 119-127, 2019.

19. Chiu ML and Gilliland GL: Engineering antibody therapeutics Curr Opin Struct Biol 38: 163-173, 2016.

20. Wootla B, Denic A and Rodriguez M: Polyclonal and monoclonal antibodies in clinic. Methods Mol Biol 1060: 79-110, 2014.

21. Köhler G and Milstein C: Continuous cultures of fused cells secreting antibody of predefined specificity. Nature 256: 495-497, 1975.

22. Miller RA, Maloney DG, Warnke R and Levy R: Treatment of B-cell lymphoma with monoclonal anti-idiotype antibody. N Engl J Med 306: 517-522, 1982.

23. An Z: Monoclonal antibodies-a proven and rapidly expanding therapeutic modality for human diseases. Protein Cell 1: 319-330, 2010.

24. Grilo AL and Mantalaris A: The increasingly human and profitable monoclonal antibody market. Trends Biotechnol 37: 9-16, 2019.

25. Garrard LJ and Zhukovsky EA: Antibody expression in bacteriophage systems: The future of monoclonal antibodies? Curr Opin Biotechnol 3: 474-480, 1992.

26. Parray HA, Shukla S, Samal S, Shrivastava T, Ahmed S, Sharma C and Kumar R: Hybridoma technology a versatile method for isolation of monoclonal antibodies, its applicability across species, limitations, advancement and future perspectives. Int Immunopharmacol 85: 106639, 2020.

27. Shim H: Antibody phage display. Adv Exp Med Biol 1053: 21-34, 2017.

28. Groves MA and Osbourn JK: Applications of ribosome display to antibody drug discovery. Expert Opin Biol Ther 5: 125-135, 2005.

29. Lu RM, Hwang YC, Liu IJ, Lee CC, Tsai HZ, Li HJ and Wu HC: Development of therapeutic antibodies for the treatment of diseases. J Biomed Sci 27: 1, 2020.

30. Schmid AS and Neri D: Advances in antibody engineering for rheumatic diseases. Nat Rev Rheumatol 15: 197-207, 2019.

31. Kuramochi T, Igawa T, Tsunoda $\mathrm{H}$ and Hattori K: Humanization and simultaneous optimization of monoclonal antibody. Methods Mol Biol 1904: 213-230, 2019.
32. Goydel RS, Weber J, Peng H, Qi J, Soden J, Freeth J, Park H and Rader C: Affinity maturation, humanization, and co-crystallization of a rabbit anti-human ROR2 monoclonal antibody for therapeutic applications. J Biol Chem 295: 5995-6006, 2020.

33. Wu Y, Li C, Xia S, Tian X, Kong Y, Wang Z, Gu C, Zhang R, Tu C, Xie Y, et al: Identification of human single-domain antibodies against SARS-CoV-2. Cell Host Microbe 27: 891-898.e5, 2020.

34. Frenzel A, Schirrmann T and Hust M: Phage display-derived human antibodies in clinical development and therapy. MAbs 8: 1177-1194, 2016.

35. Pucca MB, Cerni FA, Janke R, Bermúdez-Méndez E, Ledsgaard L, Barbosa JE and Laustsen AH: History of envenoming therapy and current perspectives. Front Immunol 10: $1598,2019$.

36. Ribatti D: From the discovery of monoclonal antibodies to their therapeutic application: An historical reappraisal. Immunol Lett 161: 96-99, 2014.

37. Elgundi Z, Reslan M, Cruz E, Sifniotis V and Kayser V: The state-of-play and future of antibody therapeutics. Adv Drug Deliv Rev 122: 2-19, 2017.

38. Paci A, Desnoyer A, Delahousse J, Blondel L, Maritaz C, Chaput N, Mir O and Broutin S: Pharmacokinetic/pharmacodynamic relationship of therapeutic monoclonal antibodies used in oncology: Part 1, monoclonal antibodies, antibody-drug conjugates and bispecific T-cell engagers. Eur J Cancer 128: 107-118, 2020.

39. Zaroff S and Tan G: Hybridoma technology: The preferred method for monoclonal antibody generation for in vivo applications. Biotechniques 67: 90-92, 2019.

40. Schroff RW, Foon KA, Beatty SM, Oldham RK and Morgan AC Jr: Human anti-murine immunoglobulin responses in patients receiving monoclonal antibody therapy. Cancer Res 45: 879-885, 1985.

41. Angus DC, Birmingham MC, Balk RA, Scannon PJ, Collins D, Kruse JA, Graham DR, Dedhia HV, Homann S and MacIntyre N: E5 murine monoclonal antiendotoxin antibody in gram-negative sepsis: A randomized controlled trial. E5 study investigators. JAMA 283: 1723-1730, 2000

42. Karmali R, Kimby E, Ghielmini M, Flinn IW, Gordon LI and Zucca E: Rituximab: A benchmark in the development of chemotherapy-free treatment strategies for follicular lymphomas. Ann Oncol 29: 332-340, 2018.

43. Crowe JE Jr: Recent advances in the study of human antibody responses to influenza virus using optimized human hybridoma approaches. Vaccine 27 (Suppl 6): G47-G51, 2009.

44. Gonzales NR, De Pascalis R, Schlom J and Kashmiri SV: Minimizing the immunogenicity of antibodies for clinical application. Tumour Biol 26: 31-43, 2005.

45. Alfaleh MA, Alsaab HO, Mahmoud AB, Alkayyal AA, Jones ML, Mahler SM and Hashem AM: Phage display derived monoclonal antibodies: From bench to bedside. Front Immunol 11: 1986 , 2020.

46. LoBuglio AF, Wheeler RH, Trang J, Haynes A, Rogers K, Harvey EB, Sun L, Ghrayeb J and Khazaeli MB: Mouse/human chimeric monoclonal antibody in man: Kinetics and immune response. Proc Natl Acad Sci USA 86: 4220-4224, 1989.

47. Targan SR, Hanauer SB, van Deventer SJ, Mayer L, Present DH, Braakman T, DeWoody KL, Schaible TF and Rutgeerts PJ: A short-term study of chimeric monoclonal antibody cA2 to tumor necrosis factor alpha for Crohn's disease. Crohn's disease cA2 study group. N Engl J Med 337: 1029-1035, 1997.

48. Liu AY, Robinson RR, Murray ED Jr, Ledbetter JA, Hellström I and Hellström KE: Production of a mouse-human chimeric monoclonal antibody to $\mathrm{CD} 20$ with potent $\mathrm{Fc}$-dependent biologic activity. J Immunol 139: 3521-3526, 1987.

49. McLaughlin P, Grillo-López AJ, Link BK, Levy R, Czuczman MS, Williams ME, Heyman MR, Bence-Bruckler I, White CA, Cabanillas F, et al: Rituximab chimeric anti-CD20 monoclonal antibody therapy for relapsed indolent lymphoma: Half of patients respond to a four-dose treatment program. J Clin Oncol 16: 2825-2833, 1998

50. Piccolo R, Eitel I, Galasso G, Dominguez-Rodriguez A, Iversen AZ, Abreu-Gonzalez P, Windecker S, Thiele $\mathrm{H}$ and Piscione F: 1-Year outcomes with intracoronary abciximab in diabetic patients undergoing primary percutaneous coronary intervention. J Am Coll Cardiol 68: 727-738, 2016

51. Bachlava E,Loukopoulou S, Karanasios E, Chrousos G and Michos A: Management of coronary artery aneurysms using abciximab in children with Kawasaki disease. Int J Cardiol 220: 65-69, 2016. 
52. Liu SN, Zhang XH, Xu LP, Wang Y, Yan CH, Chen H, Chen YH, Han W, Wang FR, Wang JZ, et al: Prognostic factors and long-term follow-up of basiliximab for steroid-refractory acute graft-versus-host disease: Updated experience from a large-scale study. Am J Hematol 95: 927-936, 2020.

53. Furuya Y, Jayarajan SN, Taghavi S, Cordova FC, Patel N, Shiose A, Leotta E, Criner GJ, Guy TS, Wheatley GH, et al: The impact of alemtuzumab and basiliximab induction on patient survival and time to bronchiolitis obliterans syndrome in double lung transplantation recipients. Am J Transplant 16: 2334-2341, 2016.

54. Aranda E, García-Alfonso P, Benavides M, Sánchez Ruiz A, Guillén-Ponce C, Safont MJ, Alcaide J, Gómez A, López R, Manzano JL, et al: First-line mFOLFOX plus cetuximab followed by mFOLFOX plus cetuximab or single-agent cetuximab as maintenance therapy in patients with metastatic colorectal cancer: Phase II randomised MACRO2 TTD study. Eur J Cancer 101: 263-272, 2018.

55. Strohbehn GW and Vokes EE: Palbociclib: A new partner for cetuximab? Lancet Oncol 20: 1195-1196, 2019.

56. Strohl WR: Current progress in innovative engineered antibodies. Protein Cell 9: 86-120, 2018.

57. Presta LG: Engineering of therapeutic antibodies to minimize immunogenicity and optimize function. Adv Drug Deliv Rev 58 640-656, 2006.

58. Kumar R, Parray HA, Shrivastava T, Sinha S and Luthra K: Phage display antibody libraries: A robust approach for generation of recombinant human monoclonal antibodies. Int J Biol Macromol 135: 907-918, 2019.

59. Saw PE and Song EW: Phage display screening of therapeutic peptide for cancer targeting and therapy. Protein Cell 10: 787-807, 2019.

60. Ledsgaard L, Kilstrup M, Karatt-Vellatt A, McCafferty J and Laustsen $\mathrm{AH}$ : Basics of antibody phage display technology. Toxins (Basel) 10: 236, 2018

61. Greenwood J, Willis AE and Perham RN: Multiple display of foreign peptides on a filamentous bacteriophage. Peptides from plasmodium falciparum circumsporozoite protein as antigens. J Mol Biol 220: 821-827, 1991.

62. Smith GP: Filamentous fusion phage: Novel expression vectors that display cloned antigens on the virion surface. Science 228 1315-1317, 1985.

63. Geysen HM, Tainer JA, Rodda SJ, Mason TJ, Alexander H, Getzoff ED and Lerner RA: Chemistry of antibody binding to a protein. Science 235: 1184-1190, 1987.

64. Parmley SF and Smith GP: Antibody-selectable filamentous fd phage vectors: Affinity purification of target genes. Gene 73 305-318, 1988.

65. Scott JK and Smith GP: Searching for peptide ligands with an epitope library. Science 249: 386-390, 1990.

66. McCafferty J, Griffiths AD, Winter G and Chiswell DJ: Phage antibodies: Filamentous phage displaying antibody variable domains. Nature 348: 552-554, 1990.

67. Tan Y, Tian T, Liu W, Zhu Z and C JY: Advance in phage display technology for bioanalysis. Biotechnol J 11: 732-745, 2016.

68. Deng X, Wang L, You X, Dai P and Zeng Y: Advances in the T7 phage display system (Review). Mol Med Rep 17: 714-720, 2018

69. Burritt JB, Bond CW, Doss KW and Jesaitis AJ: Filamentous phage display of oligopeptide libraries. Anal Biochem 238: 1-13, 1996.

70. Huang J, Doria-Rose NA, Longo NS, Laub L, Lin CL, Turk E, Kang BH, Migueles SA, Bailer RT, Mascola JR and Connors M: Isolation of human monoclonal antibodies from peripheral blood B cells. Nat Protoc 8: 1907-1915, 2013.

71. Wang Z, Li Y, Hou B, Pronobis MI, Wang M, Wang Y, Cheng G, Weng W, Wang Y, Tang Y, et al: An array of 60,000 antibodies for proteome-scale antibody generation and target discovery. Sci Adv 6: eaax2271, 2020.

72. Galán A, Comor L, Horvatić A, Kuleš J, Guillemin N, Mrljak V and Bhide M: Library-based display technologies: Where do we stand? Mol Biosyst 12: 2342-2358, 2016.

73. Lim CC, Choong YS and Lim TS: Cognizance of molecular methods for the generation of mutagenic phage display antibody libraries for affinity maturation. Int J Mol Sci 20: 1861, 2019.

74. Goracci M, Pignochino Y and Marchiò S: Phage display-based nanotechnology applications in cancer immunotherapy. Molecules 25: 843, 2020.

75. Rahbarnia L, Farajnia S, Babaei H, Majidi J, Veisi K, Ahmadzadeh V and Akbari B: Evolution of phage display technology: From discovery to application. J Drug Target 25: 216-224, 2017
76. Petrenko VA: Landscape phage: Evolution from phage display to nanobiotechnology. Viruses 10: 311, 2018.

77. Brüggemann M and Neuberger MS: Strategies for expressing human antibody repertoires in transgenic mice. Immunol Today 17: 391-397, 1996.

78. Brüggemann M, Osborn MJ, Ma B, Hayre J, Avis S, Lundstrom B and Buelow R: Human antibody production in transgenic animals. Arch Immunol Ther Exp (Warsz) 63: 101-108, 2015.

79. Laffleur B, Pascal V, Sirac C and Cogné M: Production of human or humanized antibodies in mice. Methods Mol Biol 901: 149-159, 2012.

80. Chen WC and Murawsky CM: Strategies for generating diverse antibody repertoires using transgenic animals expressing human antibodies. Front Immunol 9: 460, 2018.

81. Alt FW, Blackwell TK and Yancopoulos GD: Immunoglobulin genes in transgenic mice. Trends Genet 1: 231-236, 1985.

82. Frippiat JP, Williams SC, Tomlinson IM, Cook GP, Cherif D, Le Paslier D, Collins JE, Dunham I, Winter G and Lefranc MP: Organization of the human immunoglobulin lambda light-chain locus on chromosome 22q11.2. Hum Mol Genet 4: 983-991, 1995.

83. Fishwild DM, O'Donnell SL, Bengoechea T, Hudson DV, Harding F, Bernhard SL, Jones D, Kay RM, Higgins KM, Schramm SR and Lonberg N: High-avidity human IgG kappa monoclonal antibodies from a novel strain of minilocus transgenic mice. Nat Biotechnol 14: 845-851, 1996.

84. Mendez MJ, Green LL, Corvalan JR, Jia XC, Maynard-Currie CE, Yang XD, Gallo ML, Louie DM, Lee DV, Erickson KL, et al: Functional transplant of megabase human immunoglobulin loci recapitulates human antibody response in mice. Nat Genet 15: 146-156, 1997.

85. Lonberg N: Human antibodies from transgenic animals. Nat Biotechnol 23: 1117-1125, 2005.

86. Siegel SA, Shealy DJ, Nakada MT, Le J, Woulfe DS, Probert L, Kollias G, Ghrayeb J, Vilcek J, Daddona PE: The mouse/human chimeric monoclonal antibody cA2 neutralizes TNF in vitro and protects transgenic mice from cachexia and TNF lethality in vivo. Cytokine 7: 15-25, 1995.

87. Tsujinaka T, Fujita J, Ebisui C, Yano M, Kominami E, Suzuki K, Tanaka K, Katsume A, Ohsugi Y, Shiozaki H and Monden M: Interleukin 6 receptor antibody inhibits muscle atrophy and modulates proteolytic systems in interleukin 6 transgenic mice. J Clin Invest 97: 244-249, 1996.

88. Crombet-Ramos T, Rak J, Pérez R and Viloria-Petit A: Antiproliferative, antiangiogenic and proapoptotic activity of h-R3: A humanized anti-EGFR antibody. Int J Cancer 101: 567-575, 2002

89. Jakobovits A, Amado RG, Yang X, Roskos L and Schwab G: From XenoMouse technology to panitumumab, the first fully human antibody product from transgenic mice. Nat Biotechnol 25: 1134-1143, 2007.

90. Ros F, Offner S, Klostermann S, Thorey I, Niersbach H, Breuer S, Zarnt G, Lorenz S, Puels J, Siewe B, et al: Rabbits transgenic for human IgG genes recapitulating rabbit B-cell biology to generate human antibodies of high specificity and affinity. MAbs 12: $1846900,2020$.

91. He M and Taussig MJ: Eukaryotic ribosome display with in situ DNA recovery. Nat Methods 4: 281-288, 2007.

92. Thom G and Groves M: Ribosome display. Methods Mol Biol 901: 101-116, 2012.

93. Plückthun A: Ribosome display: A perspective. Methods Mol Biol 805: 3-28, 2012.

94. Rothe A, Hosse RJ and Power BE: Ribosome display for improved biotherapeutic molecules. Expert Opin Biol Ther 6: 177-187, 2006.

95. Ministro J, Manuel AM and Goncalves J: Therapeutic antibody engineering and selection strategies. Adv Biochem Eng Biotechnol 171: 55-86, 2020.

96. Mattheakis LC, Bhatt RR and Dower WJ: An in vitro polysome display system for identifying ligands from very large peptide libraries. Proc Natl Acad Sci USA 91: 9022-9026, 1994.

97. Hammers CM and Stanley JR: Antibody phage display: Technique and applications. J Invest Dermatol 134: 1-5, 2014.

98. Loh B, Kuhn A and Leptihn S: The fascinating biology behind phage display: Filamentous phage assembly. Mol Microbiol 111: 1132-1138, 2019.

99. Zahnd C, Amstutz P and Plückthun A: Ribosome display: Selecting and evolving proteins in vitro that specifically bind to a target. Nat Methods 4: 269-279, 2007. 
100. Hammerling MJ, Fritz BR, Yoesep DJ, Kim DS, Carlson ED and Jewett MC: In vitro ribosome synthesis and evolution through ribosome display. Nat Commun 11: 1108, 2020.

101. He M and Khan F: Ribosome display: Next-generation display technologies for production of antibodies in vitro. Expert Rev Proteomics 2: 421-430, 2005.

102. Lagoutte P, Lugari A, Elie C, Potisopon S, Donnat S, Mignon C Mariano N, Troesch A, Werle B and Stadthagen G: Combination of ribosome display and next generation sequencing as a powerful method for identification of affibody binders against $\beta$-lactamase CTX-M15. N Biotechnol 50: 60-69, 2019.

103. RouetR, Jackson KJL, Langley DB and Christ D: Next-generation sequencing of antibody display repertoires. Front Immunol 9: $118,2018$.

104. Yamaguchi J, Naimuddin M, Biyani M, Sasaki T, Machida M, Kubo T, Funatsu T, Husimi Y and Nemoto N: cDNA display: A novel screening method for functional disulfide-rich peptides by solid-phase synthesis and stabilization of mRNA-protein fusions. Nucleic Acids Res 37: e108, 2009.

105. Lipovsek D and Plückthun A: In-vitro protein evolution by ribosome display and mRNA display. J Immunol Methods 290 : $51-67,2004$

106. Ueda T, Kanamori T and Ohashi H: Ribosome display with the PURE technology. Methods Mol Biol 607: 219-225, 2010.

107. Roberts RW and Szostak JW: RNA-peptide fusions for the in vitro selection of peptides and proteins. Proc Natl Acad Sci USA 94: 12297-12302, 1997.

108. Muranaka N, Hohsaka T and Sisido M: Four-base codon mediated mRNA display to construct peptide libraries that contain multiple nonnatural amino acids. Nucleic Acids Res 34: e7, 2006.

109. Dufner P, Jermutus L and Minter RR: Harnessing phage and ribosome display for antibody optimisation. Trends Biotechnol 24 523-529, 2006.

110. Wardemann H, Yurasov S, Schaefer A, Young JW, Meffre E and Nussenzweig MC: Predominant autoantibody production by early human B cell precursors. Science 301: 1374-1377, 2003.

111. Traggiai E, Becker S, Subbarao K, Kolesnikova L, Uematsu Y, Gismondo MR, Murphy BR, Rappuoli R and Lanzavecchia A: An efficient method to make human monoclonal antibodies from memory B cells: Potent neutralization of SARS coronavirus. Nat Med 10: 871-875, 2004.

112. Bushey RT, Moody MA, Nicely NL, Haynes BF, Alam SM, Keir ST, Bentley RC, Roy Choudhury K, Gottlin EB, Campa MJ, et al: A Therapeutic antibody for cancer, derived from single human B cells. Cell Rep 15: 1505-1513, 2016.

113. Tiller T: Single B cell antibody technologies. N Biotechnol 28 : 453-457, 2011

114. Rudkin FM, Raziunaite I, Workman H, Essono S, Belmonte R, MacCallum DM, Johnson EM, Silva LM, Palma AS, Feizi T, et al: Single human B cell-derived monoclonal anti-Candida antibodies enhance phagocytosis and protect against disseminated candidiasis. Nat Commun 9: 5288, 2018.

115. Rajan S, Kierny MR, Mercer A, Wu J, Tovchigrechko A, Wu H, Dall Acqua WF, Xiao X and Chowdhury PS: Recombinan human B cell repertoires enable screening for rare, specific, and natively paired antibodies. Commun Biol 1: 5, 2018.

116. Buisman AM, de Rond CG, Oztürk K, Ten Hulscher HI and van Binnendijk RS: Long-term presence of memory B-cells specific for different vaccine components. Vaccine 28: 179-186, 2009.

117. Jilg W, Schmidt M and Deinhardt F: Decline of anti-HBs after hepatitis B vaccination and timing of revaccination. Lancet 335 173-174, 1990.

118. Inoue T, Moran I, Shinnakasu R, Phan TG and Kurosaki T: Generation of memory B cells and their reactivation. Immunol Rev 283: 138-149, 2018.

119. von Bredow B, Arias JF, Heyer LN, Moldt B, Le K, Robinson JE Zolla-Pazner S, Burton DR and Evans DT: Comparison of antibody-dependent cell-mediated cytotoxicity and virus neutralization by HIV-1 Env-specific monoclonal antibodies. J Virol 90: 6127-6139, 2016.

120. von Boehmer L, Liu C, Ackerman S, Gitlin AD, Wang Q, Gazumyan A and Nussenzweig MC: Sequencing and cloning of antigen-specific antibodies from mouse memory B cells. Na Protoc 11: 1908-1923, 2016.

121. Lei L, Tran K, Wang Y, Steinhardt JJ, Xiao Y, Chiang CI Wyatt RT and Li Y: Antigen-specific single B cell sorting and monoclonal antibody cloning in guinea pigs. Front Microbiol 10: $672,2019$.
122. Cao Y, Su B, Guo X, Sun W, Deng Y, Bao L, Zhu Q, Zhang X, Zheng Y, Geng $\mathrm{C}$, et al: Potent neutralizing antibodies against SARS-CoV-2 identified by high-throughput single-cell sequencing of convalescent patients' B cells. Cell 182: 73-84.e16, 2020.

123. Lanzavecchia A, Corti D and Sallusto F: Human monoclonal antibodies by immortalization of memory B cells. Curr Opin Biotechnol 18: 523-528, 2007.

124. Wrammert J, Koutsonanos D, Li GM, Edupuganti S, Sui J, Morrissey M, McCausland M, Skountzou I, Hornig M, Lipkin WI, et al: Broadly cross-reactive antibodies dominate the human B cell response against 2009 pandemic H1N1 influenza virus infection. J Exp Med 208: 181-193, 2011.

125. Hafeez U, Gan HK and Scott AM: Monoclonal antibodies as immunomodulatory therapy against cancer and autoimmune diseases. Curr Opin Pharmacol 41: 114-121, 2018.

126. Walcheck B and Wu J: iNK-CD64/16A cells: A promising approach for ADCC? Expert Opin Biol Ther 19: 1229-1232, 2019.

127. Decaup E, Rossi C, Gravelle P, Laurent C, Bordenave J, Tosolini M, Tourette A, Perrial E, Dumontet C, Poupot M, et al: A tridimensional model for NK cell-mediated ADCC of follicular lymphoma. Front Immunol 10: 1943, 2019.

128. Giles AJ, Hao S, Padget M, Song H, Zhang W, Lynes J, Sanchez V, Liu Y, Jung J, Cao X, et al: Efficient ADCC killing of meningioma by avelumab and a high-affinity natural killer cell line, haNK. JCI Insight 4: e130688, 2019.

129. Pockley AG, Vaupel P and Multhoff G: NK cell-based therapeutics for lung cancer. Expert Opin Biol Ther 20: 23-33, 2020.

130. Adams GP and Weiner LM: Monoclonal antibody therapy of cancer. Nat Biotechnol 23: 1147-1157, 2005.

131. Seguin-Devaux C, Plesseria JM, Verschueren C, Masquelier C, Iserentant G, Fullana M, Józsi M, Cohen JHM and Dervillez X: FHR4-based immunoconjugates direct complement-dependent cytotoxicity and phagocytosis towards HER2-positive cancer cells. Mol Oncol 13: 2531-2553, 2019.

132. Wyant T, Fedyk E and Abhyankar B: An overview of the mechanism of action of the monoclonal antibody vedolizumab. J Crohns Colitis 10: 1437-1444, 2016.

133. Czyz M: Fibroblast growth factor receptor signaling in skin cancers. Cells 8: 540, 2019

134. Jimenez-Pascual A and Siebzehnrubl FA: Fibroblast growth factor receptor functions in glioblastoma. Cells 8: 715, 2019.

135. Lee YT, Tan YJ and Oon CE: Molecular targeted therapy: Treating cancer with specificity. Eur J Pharmacol 834: 188-196, 2018.

136. Weiner GJ: Building better monoclonal antibody-based therapeutics. Nat Rev Cancer 15: 361-370, 2015.

137. Howie LJ, Scher NS, Amiri-Kordestani L, Zhang L, King-Kallimanis BL, Choudhry Y, Schroeder J, Goldberg KB, Kluetz PG,Ibrahim A, et al: FDA approval summary: Pertuzumab for adjuvant treatment of HER2-positive early breast cancer. Clin Cancer Res 25: 2949-2955, 2019.

138. Touat M, Idbaih A, Sanson M and Ligon KL: Glioblastoma targeted therapy: Updated approaches from recent biological insights. Ann Oncol 28: 1457-1472, 2017.

139. Xu MJ, Johnson DE and Grandis JR: EGFR-targeted therapies in the post-genomic era. Cancer Metastasis Rev 36: 463-473, 2017.

140. Frezzetti D, Gallo M, Maiello MR, D'Alessio A, Esposito C, Chicchinelli N, Normanno N and De Luca A: VEGF as a potential target in lung cancer. Expert Opin Ther Targets 21: 959-966, 2017

141. Yalcin F, Dzaye $\mathrm{O}$ and Xia S: Tenascin-C function in glioma: Immunomodulation and beyond. Adv Exp Med Biol 1272: $149-172,2020$

142. Lieverse RIY, Van Limbergen EJ, Oberije CJG, Troost EGC, Hadrup SR, Dingemans AC, Hendriks LEL, Eckert F, Hiley C, Dooms C, et al: Stereotactic ablative body radiotherapy (SABR) combined with immunotherapy (L19-IL2) versus standard of care in stage IV NSCLC patients, ImmunoSABR: A multicentre, randomised controlled open-label phase II trial. BMC Cancer 20: 557, 2020.

143. Wester HJ and Schottelius M: PSMA-targeted radiopharmaceuticals for imaging and therapy. Semin Nucl Med 49: 302-312, 2019

144. Apte RS, Chen DS and Ferrara N: VEGF in signaling and disease: Beyond discovery and development. Cell 176: 1248-1264, 2019.

145. Topalian SL, Taube JM, Anders RA and Pardoll DM Mechanism-driven biomarkers to guide immune checkpoint blockade in cancer therapy. Nat Rev Cancer 16: 275-287, 2016 
146. Zhang JC, Chen WD, Alvarez JB, Jia K, Shi L, Wang Q, Zou N, $\mathrm{He} \mathrm{K}$ and Zhu H: Cancer immune checkpoint blockade therapy and its associated autoimmune cardiotoxicity. Acta Pharmacol Sin 39: 1693-1698, 2018

147. Chamoto K, Al-Habsi M and Honjo T: Role of PD-1 in immunity and diseases. Curr Top Microbiol Immunol 410: 75-97, 2017.

148. Darvin P, Toor SM, Sasidharan Nair V and Elkord E: Immune checkpoint inhibitors: Recent progress and potential biomarkers. Exp Mol Med 50: 1-11, 2018.

149. Postow MA, Sidlow R and Hellmann MD: Immune-related adverse events associated with immune checkpoint blockade. N Engl J Med 378: 158-168, 2018.

150. Gotwals P, Cameron S, Cipolletta D, Cremasco V, Crystal A, Hewes B, Mueller B, Quaratino S, Sabatos-Peyton C, Petruzzelli L, et al: Prospects for combining targeted and conventional cancer therapy with immunotherapy. Nat Rev Cancer 17: 286-301, 2017.

151. Abril-Rodriguez G and Ribas A: SnapShot: Immune checkpoint inhibitors. Cancer Cell 31: 848-848.e1, 2017.

152. Rowshanravan B, Halliday N and Sansom DM: CTLA-4: A moving target in immunotherapy. Blood 131: 58-67, 2018.

153. Lo B and Abdel-Motal UM: Lessons from CTLA-4 deficiency and checkpoint inhibition. Curr Opin Immunol 49: 14-19, 2017.

154. Duperret EK, Trautz A, Stoltz R, Patel A, Wise MC, Perales-Puchalt A, Smith T, Broderick KE, Masteller E, Kim JJ, et al: Synthetic DNA-encoded monoclonal antibody delivery of anti-CTLA-4 antibodies induces tumor shrinkage in vivo. Cancer Res 78: 6363-6370, 2018

155. Specenier P: Ipilimumab in melanoma. Expert Rev Anticancer Ther 16: 811-826, 2016

156. Carter BW, Bhosale PR and Yang WT: Immunotherapy and the role of imaging. Cancer 124: 2906-2922, 2018.

157. Kuehn HS, Ouyang W, Lo B, Deenick EK, Niemela JE, Avery DT, Schickel JN, Tran DQ, Stoddard J, Zhang Y, et al: Immune dysregulation in human subjects with heterozygous germline mutations in CTLA4. Science 345: 1623-1627, 2014

158. Schubert D, Bode C, Kenefeck R, Hou TZ, Wing JB, Kennedy A, Bulashevska A, Petersen BS, Schäffer AA, Grüning BA, et al: Autosomal dominant immune dysregulation syndrome in humans with CTLA4 mutations. Nat Med 20: 1410-1416, 2014.

159. Chesney J, Puzanov I, Collichio F, Singh P, Milhem MM, Glaspy J, Hamid O, Ross M, Friedlander P, Garbe C, et al: Randomized, open-label phase II study evaluating the efficacy and safety of talimogene laherparepvec in combination with ipilimumab versus ipilimumab alone in patients with advanced, unresectable melanoma. J Clin Oncol 36: 1658-1667, 2018.

160. Soularue E, Lepage P, Colombel JF, Coutzac C, Faleck D, Marthey L, Collins M, Chaput N, Robert C and Carbonnel F: Enterocolitis due to immune checkpoint inhibitors: A systematic review. Gut 67: 2056-2067, 2018.

161. Spain L, Diem S and Larkin J: Management of toxicities of immune checkpoint inhibitors. Cancer Treat Rev 44: 51-60, 2016.

162. Rotte A: Combination of CTLA-4 and PD-1 blockers for treatment of cancer. J Exp Clin Cancer Res 38: 255, 2019.

163. Larkin J, Chiarion-Sileni V, Gonzalez R, Grob JJ, Rutkowski P, Lao CD, Cowey CL, Schadendorf D, Wagstaff J, Dummer R, et al: Five-year survival with combined nivolumab and ipilimumab in advanced melanoma. N Engl J Med 381: 1535-1546, 2019.

164. Sidaway P: Immunotherapy: Local chemotherapy synergizes with CTLA-4 inhibition. Nat Rev Clin Oncol 15: 202, 2018.

165. Weber JS, Kähler KC and Hauschild A: Management of immune-related adverse events and kinetics of response with ipilimumab. J Clin Oncol 30: 2691-2697, 2012.

166. Han Y, Liu D and Li L: PD-1/PD-L1 pathway: Current researches in cancer. Am J Cancer Res 10: 727-742, 2020.

167. Alsaab HO, Sau S, Alzhrani R, Tatiparti K, Bhise K, Kashaw SK and Iyer AK: PD-1 and PD-L1 checkpoint signaling inhibition for cancer immunotherapy: Mechanism, combinations, and clinical outcome. Front Pharmacol 8: 561, 2017.

168. Xu-Monette ZY, Zhou J and Young KH: PD-1 expression and clinical PD-1 blockade in B-cell lymphomas. Blood 131: 68-83, 2018.

169. Du S, McCall N, Park K, Guan Q, Fontina P, Ertel A, Zhan T, Dicker AP and Lu B: Blockade of tumor-expressed PD-1 promotes lung cancer growth. Oncoimmunology 7: e1408747, 2018

170. Yi M, Jiao D, Xu H, Liu Q, Zhao W, Han X and Wu K: Biomarkers for predicting efficacy of PD-1/PD-L1 inhibitors. Mol Cancer 17: 129, 2018.
171. Naidoo J, Page DB, Li BT, Connell LC, Schindler K, Lacouture ME, Postow MA and Wolchok JD: Toxicities of the anti-PD-1 and anti-PD-L1 immune checkpoint antibodies. Ann Oncol 26: 2375-2391, 2015.

172. Sunshine J and Taube JM: PD-1/PD-L1 inhibitors. Curr Opin Pharmacol 23: 32-38, 2015

173. Patel SA and Minn AJ: Combination cancer therapy with immune checkpoint blockade: Mechanisms and strategies. Immunity 48: 417-433, 2018.

174. Hayashi $\mathrm{H}$ and Nakagawa K: Combination therapy with PD-1 or PD-L1 inhibitors for cancer. Int J Clin Oncol 25: 818-830, 2020.

175. Aggen DH, Drake CG and Rini BI: Targeting PD-1 or PD-L1 in metastatic kidney cancer: Combination therapy in the first-line setting. Clin Cancer Res 26: 2087-2095, 2020.

176. Mathew M, Enzler T, Shu CA and Rizvi NA: Combining chemotherapy with PD-1 blockade in NSCLC. Pharmacol Ther 186: 130-137, 2018

177. Kong Y, Zhao X, Zou L, Xing P, Ma Y, Tian Y and Zhang L: PD-1 inhibitor combined with radiotherapy and GM-CSF as salvage therapy in patients with chemotherapy-refractory metastatic solid tumors. J Clin Oncol 38 (Suppl 15): e15173, 2020.

178. Kordbacheh T, Honeychurch J, Blackhall F, Faivre-Finn C and Illidge T: Radiotherapy and anti-PD-1/PD-L1 combinations in lung cancer: Building better translational research platforms. Ann Oncol 29: 301-310, 2018

179. Walshaw RC, Honeychurch J, Illidge TM and Choudhury A: The anti-PD-1 era-an opportunity to enhance radiotherapy for patients with bladder cancer. Nat Rev Urol 15: 251-259, 2018.

180. Sheng X, Yan X, Chi Z, Si L, Cui C, Tang B, Li S, Mao L, Lian B, Wang $\mathrm{X}$, et al: Axitinib in combination with toripalimab, a humanized immunoglobulin $\mathrm{G}_{4}$ monoclonal antibody against programmed cell death-1, in patients with metastatic mucosal melanoma: An open-label phase IB trial. J Clin Oncol 37: 2987-2999, 2019.

181. Kato Y, Tabata K, Kimura T, Yachie-Kinoshita A, Ozawa Y, Yamada K, Ito J, Tachino S, Hori Y, Matsuki M, et al: Lenvatinib plus anti-PD-1 antibody combination treatment activates $\mathrm{CD}^{+}$ $\mathrm{T}$ cells through reduction of tumor-associated macrophage and activation of the interferon pathway. PLoS One 14: e0212513, 2019.

182. Atkins MB, Plimack ER, Puzanov I, Fishman MN, McDermott DF, Cho DC, Vaishampayan U, George S, Olencki TE, Tarazi JC, et al: Axitinib in combination with pembrolizumab in patients with advanced renal cell cancer: A non-randomised, open-label, dose-finding, and dose-expansion phase $1 b$ trial. Lancet Oncol 19: 405-415, 2018.

183. Kohlhapp FJ and Kaufman HL: Molecular pathways: Mechanism of action for talimogene laherparepvec, a new oncolytic virus immunotherapy. Clin Cancer Res 22: 1048-1054, 2016.

184. Kowalsky SJ, Liu Z, Feist M, Berkey SE, Ma C, Ravindranathan R, Dai E, Roy EJ, Guo ZS and Bartlett DL: Superagonist IL-15-armed oncolytic virus elicits potent antitumor immunity and therapy that are enhanced with PD-1 blockade. Mol Ther 26: 2476-2486, 2018.

185. Sahin U and Türeci Ö: Personalized vaccines for cancer immunotherapy. Science 359: 1355-1360, 2018.

186. Sui H, Ma N, Wang Y, Li H, Liu X, Su Y and Yang J: Anti-PD-1/PD-L1 therapy for non-small-cell lung cancer: Toward personalized medicine and combination strategies. J Immunol Res 2018: 6984948, 2018.

187. Rafiq S, Yeku OO, Jackson HJ, Purdon TJ, van Leeuwen DG, Drakes DJ, Song M, Miele MM, Li Z, Wang P, et al: Targeted delivery of a PD-1-blocking scFv by CAR-T cells enhances anti-tumor efficacy in vivo. Nat Biotechnol 36: 847-856, 2018

188. Shi X, Zhang D, Li F, Zhang Z, Wang S, Xuan Y, Ping Y and Zhang Y: Targeting glycosylation of PD-1 to enhance CAR-T cell cytotoxicity. J Hematol Oncol 12: 127, 2019.

189. Xu J, Sun HH, Fletcher CD, Hornick JL, Morgan EA, Freeman GJ, Hodi FS, Pinkus GS and Rodig SJ: Expression of programmed cell death 1 ligands (PD-L1 and PD-L2) in histiocytic and dendritic cell disorders. Am J Surg Pathol 40: 443-453, 2016

190. Xia L, Liu Y and Wang Y: PD-1/PD-L1 blockade therapy in advanced non-small-cell lung cancer: Current status and future directions. Oncologist 24 (Suppl 1): S31-S41, 2019.

191. Chaudhri A, Xiao Y, Klee AN, Wang X, Zhu B and Freeman GJ: PD-L1 binds to B7-1 only in Cis on the same cell surface. Cancer Immunol Res 6: 921-929, 2018. 
192. Inman BA, Longo TA, Ramalingam S and Harrison MR: Atezolizumab: A PD-L1-blocking antibody for bladder cancer. Clin Cancer Res 23: 1886-1890, 2017.

193. Garassino MC, Cho BC, Kim JH, Mazières J, Vansteenkiste J, Lena H, Corral Jaime J, Gray JE, Powderly J, Chouaid C, et al: Durvalumab as third-line or later treatment for advanced non-small-cell lung cancer (ATLANTIC): An open-label, single-arm, phase 2 study. Lancet Oncol 19: 521-536, 2018.

194. Lui Y and Davis SJ: LAG-3: A very singular immune checkpoint. Nat Immunol 19: 1278-1279, 2018

195. Maruhashi T, Sugiura D, Okazaki IM and Okazaki T: LAG-3: From molecular functions to clinical applications. J Immunother Cancer 8: e001014, 2020.

196. Anderson AC, Joller N and Kuchroo VK: Lag-3, Tim-3, and TIGIT: Co-inhibitory receptors with specialized functions in immune regulation. Immunity 44: 989-1004, 2016.

197. Das M, Zhu C and Kuchroo VK: Tim-3 and its role in regulating anti-tumor immunity. Immunol Rev 276: 97-111, 2017.

198. Thomas A, Teicher BA and Hassan R: Antibody-drug conjugates for cancer therapy. Lancet Oncol 17: e254-e262, 2016.

199. Sharabi AB, Lim M, DeWeese TL and Drake CG: Radiation and checkpoint blockade immunotherapy: Radiosensitisation and potential mechanisms of synergy. Lancet Oncol 16: e498-e509, 2015

200. Yaghoubi S, Karimi MH,Lotfinia M, Gharibi T,Mahi-Birjand M, Kavi E, Hosseini F, Sineh Sepehr K, Khatami M, Bagheri N, et al: Potential drugs used in the antibody-drug conjugate (ADC) architecture for cancer therapy. J Cell Physiol 235: 31-64, 2020.

201. Qin SY, Cheng YJ, Lei Q, Zhang AQ and Zhang XZ: Combinational strategy for high-performance cancer chemotherapy. Biomaterials 171: 178-197, 2018.

202. Yu WD, Sun G, Li J, Xu J and Wang X: Mechanisms and therapeutic potentials of cancer immunotherapy in combination with radiotherapy and/or chemotherapy. Cancer Lett 452: 66-70, 2019.

203. Pérez-Herrero E and Fernández-Medarde A: Advanced targeted therapies in cancer: Drug nanocarriers, the future of chemotherapy. Eur J Pharm Biopharm 93: 52-79, 2015.

204. Nadal R and Bellmunt J: Management of metastatic bladder cancer. Cancer Treat Rev 76: 10-21, 2019.

205. Akbari B, Farajnia S, Ahdi Khosroshahi S, Safari F, Yousefi M, Dariushnejad H and Rahbarnia L: Immunotoxins in cancer therapy: Review and update. Int Rev Immunol 36: 207-219, 2017.

206. Alewine C, Hassan R and Pastan I: Advances in anticancer immunotoxin therapy. Oncologist 20: 176-185, 2015.

207. Polito L, Djemil A and Bortolotti M: Plant toxin-based immunotoxins for cancer therapy: A short overview. Biomedicines 4: $12,2016$.

208. Madhumathi J, Devilakshmi S, Sridevi S and Verma RS Immunotoxin therapy for hematologic malignancies: Where are we heading? Drug Discov Today 21: 325-332, 2016.

209. Kumar M, Thangavel C, Becker RC and Sadayappan S: Monoclonal antibody-based immunotherapy and its role in the development of cardiac toxicity. Cancers (Basel) 13: 86, 2020.

210. Tse BW, Collins A, Oehler MK, Zippelius A and Heinzelmann-Schwarz VA: Antibody-based immunotherapy for ovarian cancer: Where are we at? Ann Oncol 25: 322-331, 2014

211. Chau CH, Steeg PS and Figg WD: Antibody-drug conjugates for cancer. Lancet 394: 793-804, 2019.

212. Khongorzul P, Ling CJ, Khan FU, Ihsan AU and Zhang J: Antibody-drug conjugates: A comprehensive review. Mol Cancer Res 18: 3-19, 2020.

213. Tsuchikama K and An Z: Antibody-drug conjugates: Recent advances in conjugation and linker chemistries. Protein Cell 9: $33-46,2018$

214. Erickson HK, Park PU, Widdison WC, Kovtun YV, Garrett LM, Hoffman K, Lutz RJ, Goldmacher VS and Blättler WA: Antibody-maytansinoid conjugates are activated in targeted cancer cells by lysosomal degradation and linker-dependent intracellular processing. Cancer Res 66: 4426-4433, 2006

215. Huang Y, Lee C, Borgström P and Gjerset RA: Macrophage-mediated bystander effect triggered by tumor cell apoptosis. Mol Ther 15: 524-533, 2007.

216. Staudacher AH and Brown MP: Antibody drug conjugates and bystander killing: Is antigen-dependent internalisation required? Br J Cancer 117: 1736-1742, 2017.

217. Beck A, Goetsch L, Dumontet C and Corvaïa N: Strategies and challenges for the next generation of antibody-drug conjugates. Nat Rev Drug Discov 16: 315-337, 2017.
218. Birrer MJ, Moore KN, Betella I and Bates RC: Antibody-drug conjugate-based therapeutics: State of the science. J Natl Cancer Inst 111: 538-549, 2019

219. Mahalingaiah PK, Ciurlionis R, Durbin KR, Yeager RL, Philip BK, Bawa B, Mantena SR, Enright BP, Liguori MJ and Van Vleet TR: Potential mechanisms of target-independent uptake and toxicity of antibody-drug conjugates. Pharmacol Ther 200: 110-125, 2019.

220. Lambert JM and Berkenblit A: Antibody-drug conjugates for cancer treatment. Annu Rev Med 69: 191-207, 2018.

221. Duerr C and Friess W: Antibody-drug conjugates-stability and formulation. Eur J Pharm Biopharm 139: 168-176, 2019.

222. Theocharopoulos C, Lialios PP, Gogas H and Ziogas DC: An overview of antibody-drug conjugates in oncological practice. Ther Adv Med Oncol: Oct 4, 2020 (Epub ahead of print). doi: $10.1177 / 1758835920962997$.

223. Abdollahpour-Alitappeh M, Lotfinia M, Gharibi T, Mardaneh J, Farhadihosseinabadi B, Larki P, Faghfourian B, Sepehr KS, Abbaszadeh-Goudarzi K, Abbaszadeh-Goudarzi G, et al: Antibody-drug conjugates (ADCs) for cancer therapy: Strategies, challenges, and successes. J Cell Physiol 234: 5628-5642, 2019.

224. Liu L: Pharmacokinetics of monoclonal antibodies and Fc-fusion proteins. Protein Cell 9: 15-32, 2018.

225. Yu B and Liu D: Antibody-drug conjugates in clinical trials for lymphoid malignancies and multiple myeloma. J Hematol Oncol 12: 94, 2019.

226. Gébleux R and Casi G: Antibody-drug conjugates: Current status and future perspectives. Pharmacol Ther 167: 48-59, 2016.

227. Tiller KE and Tessier PM: Advances in antibody design. Annu Rev Biomed Eng 17: 191-216, 2015.

228. Ponziani S, Di Vittorio G, Pitari G, Cimini AM, Ardini M, Gentile R, Iacobelli S, Sala G, Capone E, Flavell DJ, et al: Antibody-drug conjugates: The new frontier of chemotherapy. Int J Mol Sci 21: 5510, 2020.

229. Kobayashi H and Choyke PL: Near-infrared photoimmunotherapy of cancer. Acc Chem Res 52: 2332-2339, 2019.

230. Ozog DM, Rkein AM, Fabi SG, Gold MH, Goldman MP, Lowe NJ, Martin GM and Munavalli GS: Photodynamic therapy: A clinical consensus guide. Dermatol Surg 42: 804-827, 2016.

231. Larue L, Myrzakhmetov B, Ben-Mihoub A, Moussaron A, Thomas N, Arnoux P, Baros F, Vanderesse R, Acherar S and Frochot C: Fighting hypoxia to improve PDT. Pharmaceuticals (Basel) 12: 163,2019.

232. Nagaya T, Nakamura Y, Okuyama S, Ogata F, Maruoka Y, Choyke PL, Allen C and Kobayashi H: Syngeneic mouse models of oral cancer are effectively targeted by anti-CD44-Based NIR-PIT. Mol Cancer Res 15: 1667-1677, 2017.

233. Mew D, Lum V, Wat CK, Towers GH, Sun CH, Walter RJ, Wright W, Berns MW and Levy JG: Ability of specific monoclonal antibodies and conventional antisera conjugated to hematoporphyrin to label and kill selected cell lines subsequent to light activation. Cancer Res 45: 4380-4386, 1985.

234. Mew D, Wat CK, Towers GH and Levy JG: Photoimmunotherapy: Treatment of animal tumors with tumor-specific monoclonal antibody-hematoporphyrin conjugates. J Immunol 130: 1473-1477, 1983

235. Wang M, Rao J, Wang M, Li X, Liu K, Naylor MF, Nordquist RE, Chen WR and Zhou F: Cancer photo-immunotherapy: From bench to bedside. Theranostics 11: 2218-2231, 2021.

236. Mitsunaga M, Ogawa M, Kosaka N, Rosenblum LT, Choyke PL and Kobayashi H: Cancer cell-selective in vivo near infrared photoimmunotherapy targeting specific membrane molecules. Nat Med 17: 1685-1691, 2011.

237. Isobe Y, Sato K, Nishinaga Y, Takahashi K, Taki S, Yasui H, Shimizu M, Endo R, Koike C, Kuramoto N, et al: Near infrared photoimmunotherapy targeting DLL3 for small cell lung cancer. EBioMedicine 52: 102632, 2020.

238. Nishimura T, Mitsunaga M, Ito K, Kobayashi H and Saruta M: Cancer neovasculature-targeted near-infrared photoimmunotherapy (NIR-PIT) for gastric cancer: Different mechanisms of phototoxicity compared to cell membrane-targeted NIR-PIT. Gastric Cancer 23: 82-94, 2020.

239. Deshaies RJ: Multispecific drugs herald a new era of biopharmaceutical innovation. Nature 580: 329-338, 2020.

240. Kaplon H, Muralidharan M, Schneider Z and Reichert JM: Antibodies to watch in 2020. MAbs 12: 1703531, 2020.

This work is licensed under a Creative Commons Attribution-NonCommercial-NoDerivatives 4.0 International (CC BY-NC-ND 4.0) License. 